WATER-RESOURCES ACTIVITIES

OF THE U.S. GEOLOGICAL SURVEY

IN PENNSYLVANIA, $1988-89$

Compiled and Edited By Robert E. Helm

U.S. GEOLOGICAL SURVEY

Open-File Report 89-273

Harrisburg, Pennsylvania 
DEPARTMENT OF THE INTERIOR

MANUEL LUJAN, JR., Secretary

U.S. GEOLOGICAL SURVEY

Dallas L. Peck, Director

For additional information write to:

District Chief

U.S. Geological Survey 4th Floor, Federal Building P.0. Box 1107

Harrisburg, Pennsylvania 17108-1107
Copies of this report can be purchased from:

U.S. Geological Survey Books and Open-File Reports Section Federal Center

Box 25425

Denver, Colorado 80225 


\section{PREFACE}

Pennsylvania, like many states, faces some serious questions concerning the availability and use of its water. How can we ensure an adequate supply of good quality water in the future? In what ways are we detrimentally altering this natural resource? How can we predict, prevent, or mitigate the effects of hydrologic natural hazards such as droughts and floods? Responses to these and similar questions depend on continually increasing the knowledge of water resources in Pennsylvania.

Collecting, analyzing, and disseminating the scientific information necessary to answer these questions is the primary mission of the Pennsylvania District of the Water Resources Division of the U.S. Geologica1 Survey. 
Water-resources mission of the U.S. Geological Survey .......... 1

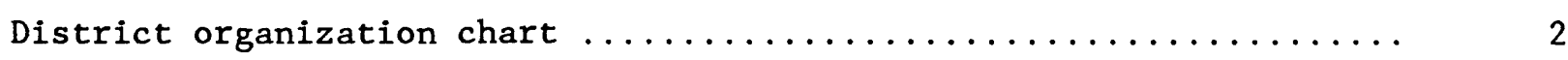

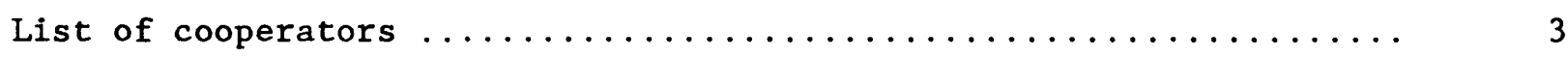

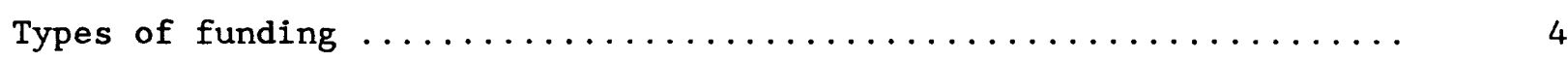

Water-Data Program $\ldots \ldots \ldots \ldots \ldots \ldots \ldots \ldots \ldots \ldots \ldots \ldots \ldots \ldots \ldots \ldots$

National Water Data Exchange $\ldots \ldots \ldots \ldots \ldots \ldots \ldots \ldots \ldots \ldots \ldots \ldots \ldots \ldots \ldots \ldots \ldots \ldots$

National Water Data Storage and Retrieval System $\ldots \ldots \ldots \ldots \ldots \ldots$

Public information service $\ldots \ldots \ldots \ldots \ldots \ldots \ldots \ldots \ldots \ldots \ldots \ldots \ldots \ldots \ldots \ldots \ldots$

Current projects $\ldots \ldots \ldots \ldots \ldots \ldots \ldots \ldots \ldots \ldots \ldots \ldots \ldots \ldots \ldots \ldots \ldots \ldots$

Recently completed projects $\ldots \ldots \ldots \ldots \ldots \ldots \ldots \ldots \ldots \ldots \ldots \ldots \ldots \ldots \ldots$

Water Resources Division publications $\ldots \ldots \ldots \ldots \ldots \ldots \ldots \ldots \ldots \ldots$

To order text products $\ldots \ldots \ldots \ldots \ldots \ldots \ldots \ldots \ldots \ldots \ldots \ldots \ldots \ldots \ldots \ldots$

Selected literature on water resources in Pennsylvania ......... 37

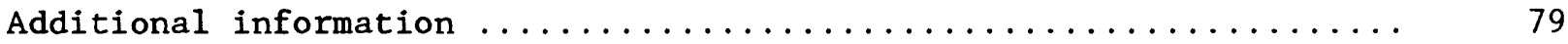




\section{MESSAGE FROM THE DISTRICT CHIEF, U.S. Geological Survey, Water Resources Division, Pennsylvania District, Harrisburg, Pennsylvania}

The mission of the U.S. Geological Survey's Pennsylvania District is accomplished by a staff of about 100 hydrologists, hydrologic technicians, and support staff who are located at offices in Harrisburg, Pittsburgh, Malvern, and Williamsport. These employees are assigned to work on hydrologic projects that have been planned and developed to address the most important water issues currently identified in Pennsylvania. This report gives a brief description of these projects and includes listings of publications describing the water resources of Pennsylvania.

The projects that are described herein are funded by a complex combination of public funds. Nearly 60 percent of the program is funded under the FederalState Cooperative Program, a program in which about 20 state and local agencies offer funds that are matched with Federal U.S. Geological Survey Cooperative funds on a 50-50 percent basis. About 30 percent of the projects are supported with funds from other Federal Agencies, and the rest of the program, less than 10 percent, is supported by U.S. Geological Survey Federal (non-cooperative) funds.

It is the policy of the Pennsylvania District to operate an issue-relevant program of water-resources investigations and data collection to the maximum extent that available funding and personnel will allow. The network of surfacewater gaging stations being operated is one of the best in the country, and over half of these stations are equipped with the most modern and technically sophisticated telemetry equipment available. Information resulting from interpretive projects provides a better understanding about some of the most demanding water-management problems currently facing the Commonwealth. Future projects will continue to seek new information and investigate more complex hydrologic systems so that water-resource-management decisions can be made with the best knowledge and understanding available.

David E. Click District Chief 
As the Nation's largest earth-science research agency, the U.S. Geological Survey maintains a long tradition of providing accurate and impartial information to all, which underscores its continued dedication to "Earth Science in the Pub1ic Service."

The Water Resources Division has the principal responsibility within the Federal Government to provide hydrologic information and understanding needed by others to achieve the best use and management of the Nation's water resources. To accomplish this mission, the Water Resources Division, in cooperation with state, local, and other Federal agencies:

- Systematically collects and analyzes data to evaluate the quantity, quality, and use of the Nation's water resources and provides results of these investigations to the public.

- Conducts water-resource appraisals describing the occurrence, availability, and physical, chemical, and biological characteristics of surface and ground water.

${ }^{\circ}$ Conducts basic and problem-oriented hydrologic and related research that aids in alleviating water-resources problems and provides an understanding of hydrologic systems sufficient to predict their response to natural or human-caused stress.

- Coordinates the activities of Federal agencies in the acquisition of water-resources data for streams, lakes, reservoirs, estuaries, and ground water.

- Provides scientific and technical assistance in hydrologic fields to other Federal, state, and local agencies, to licensees of the Federal Energy Regulatory Commission, and to international agencies on behalf of the Department of State.

-Administers the State Water Resources Research Institutes Program and the National Water Resources Research Grants Program. 


\section{DISTRICT ORGANIZATION CHART}

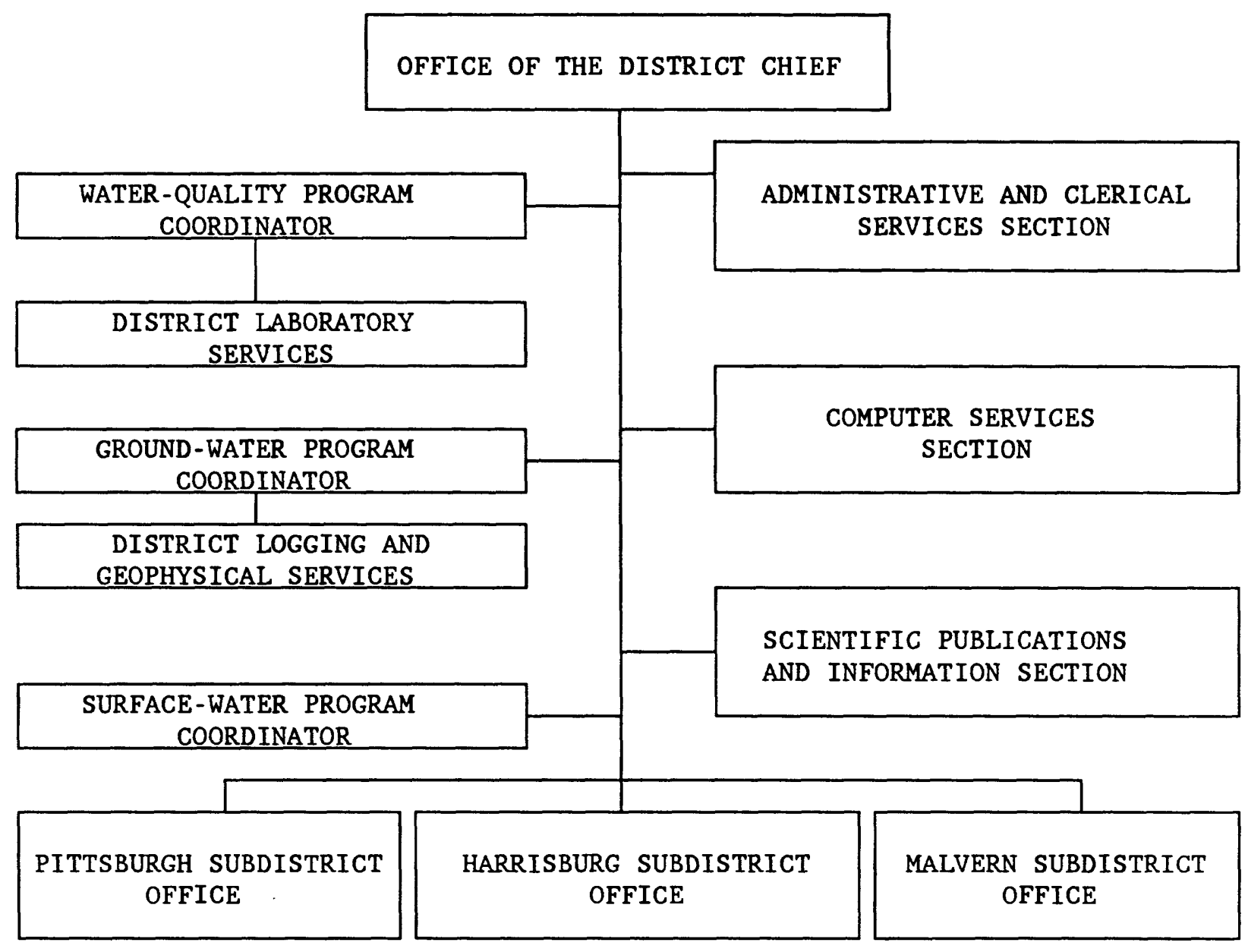

PENNSYLVANIA DISTRICT OFFICE ADDRESSES

DISTRICT OFFICE: (717) 782-4514

HARRISBURG SUBDISTRICT OFFICE:

(717) $782-4515$

Williamsport Field office:

(717) $323-7736$

PITTSBURGH SUBDISTRICT OFFICE:

(412) 644-2863

MALVERN SUBDISTRICT OFFICE:

(215) 647-9008
U.S. Geological Survey Water Resources Division Federal Building P.O. Box 1107 Harrisburg, PA 17108

Same as above

P.O. Box 1805

Room 301 Federal Building Williamsport, PA 17703

Room 2204 Federal Building 1000 Liberty Avenue Pittsburgh, PA 15222

111 Great Valley Parkway Malvern, PA 19355 


\title{
LIST OF COOPERATORS
}

\author{
Agencies Supporting Water-Resources Investigations \\ during Fiscal Years 1988-89
}

\section{Commonwealth of Pennsylvania Agencies}

\author{
Department of Agriculture (PDA) \\ Department of Environmental Resources (PaDER) \\ Bureau of Water Resources Management \\ Bureau of Topographic and Geologic Survey \\ Bureau of Mining and Reclamation \\ Bureau of Water Quality Management \\ Bureau of Community Environmental Control
}

\section{Local Agencies}

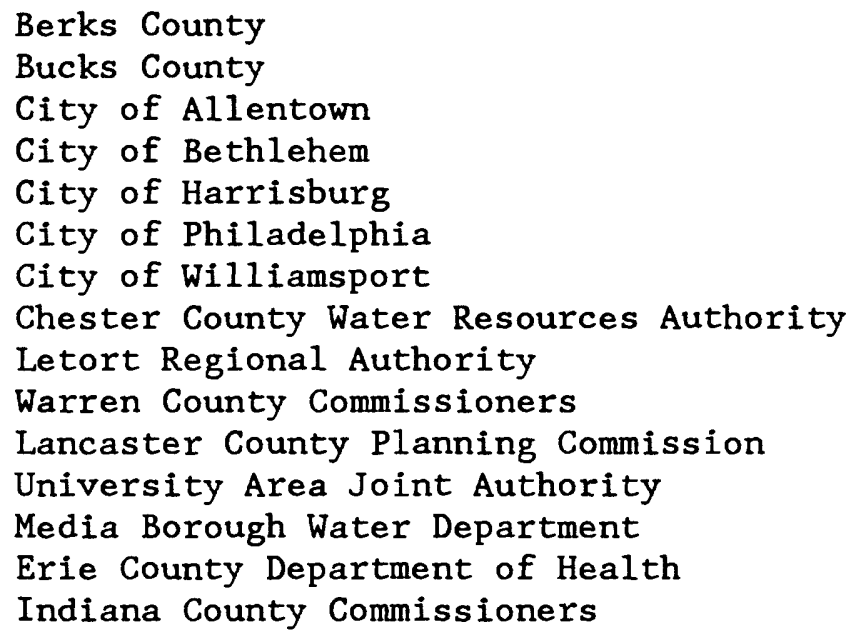

\section{Federal Agencies}

Federal Energy Regulatory Commission

Federal Emergency Management Agency (FEMA)

U.S. Department of Interior, Office of Surface Mining

U.S. Environmental Protection Agency (USEPA)

U.S. Army Corps of Engineers

Baltimore District

Philadelphia District

Pittsburgh District

U.S. Department of Commerce, National Oceanic and Atmospheric Administration, National Weather Service (NOAA)

\section{Other Agencies}

Delaware River Basin Commission (DRBC)

New York State Department of Environmental Conservation

State of Delaware Geological Survey

Susquehanna River Basin Commission (SRBC)

The Academy of Natural Science of Philadelphia 
The diagram below shows the percentage of the investigations for fiscal years 1988 and 1989 in each of the broad categories of collection of hydrologic data and interpretive studies (areal appraisals and applied research projects):

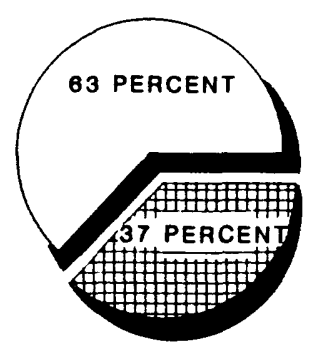

\section{EXPLANATION}

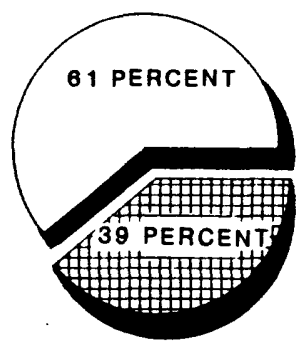

Interpretive studies

These investigations are directed toward obtaining the information needed by managers and planners for the solution of water problems in the Commonwealth. They are supported by services and funds provided by the Commonwealth and other agencies and matched on a 50-50 basis by Federal funds (cooperative program); by funds transferred from Other Federal Agencies (OFA program); and by funds appropriated directly to the U.S. Geological Survey (Federal program). The diagram below shows the percentage of funding for fiscal years 1988 and 1989.

\section{SOURCES OF FUNDS AND TOTAL PROGRAM FOR:}

FISCAL YEAR 1988

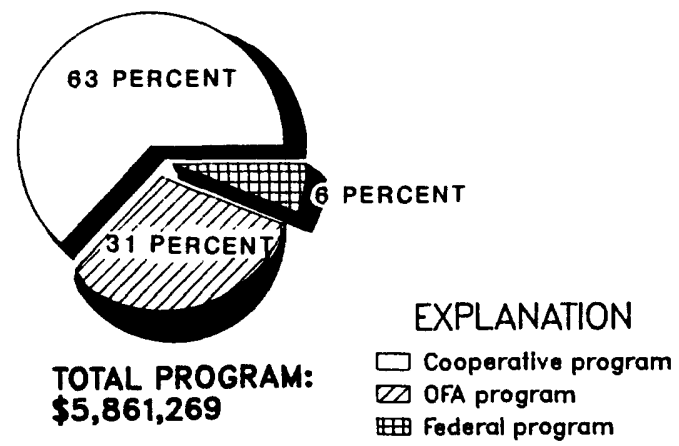

FISCAL YEAR 1989

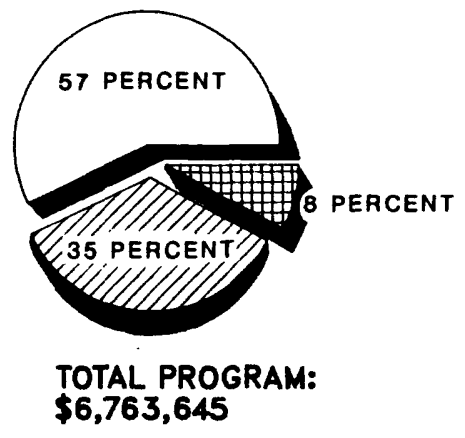


Water-data stations at selected locations throughout the nation are used by the U.S. Geological Survey to obtain records on stream discharge (flow) and stage (height), reservoir and lake stage and storage, ground-water levels, well and spring discharge, and the quality of surface and ground water. These data provide a continuing record of the quantity and quality of the Nation's surfaceand ground-water resources, and thus provide the hydrologic information needed by Federal, state, and local agencies and the private sector for the development and management of land and water resources. All data collected are stored in the Survey's National Water Data Storage and Retrieval System (see section "WATSTORE" for additional information on this system) and also are published by water year for each state in a publication series entitled "U.S. Geological Survey Water-Data Reports." Information about the Water-Data Program in Pennsylvania can be obtained from the District Chief of the Pennsylvania office.

NAWDEX (NATIONAL WATER DATA EXCHANGE)

The National Water Data Exchange is a confederation of Federal and non-Federal water-oriented organizations working together to improve access to available water data. It is managed by a Program office, which is administered by the Water Resources Division. Information on sites for which water data are available, the types of data available, and the organizations that store the data is available from NAWDEX. Assistance in identifying, locating, and acquiring data is provided by the Program Office at Reston, Virginia, by NAWDEX Assistance Centers at the Water Resources Division District offices, and by offices of other NAWDEX member organizations. A directory of assistance centers, and more detailed information about services, can be obtained from the NAWDEX Program office, Branch of Water Information Transfer. The NAWDEX headquarters address is: National Water Data Exchange, U.S. Geological Survey, 421 National Center, Reston, VA 22092. The office may be reached by phone at (703) $648-5677$.

\section{WATSTORE (NATIONAL WATER-DATA STORAGE AND RETRIEVAL SYSTEM)}

As explained in the section "Water-Data Program," all data collected through that program are stored in WATSTORE, and the data are available on request. These data can be retrieved in machine-readable form or as computer printed tables or graphs, statistical analyses, and digital plots. Local assistance in the acquisition of service or products from WATSTORE can be obtained from the District offices. A pamphlet, "WATSTORE: A WATer Data STOrage and REtrieval System," may be obtained from these offices or from the WATSTORE Program office, Branch of Computer Technology, U.S. Geological Survey, 440 National Center, Reston, VA 22092. The office may be reached by phone at (703) $648-5680$. 
Along with its continuing commitment to meet the earth-science needs of the Nation, the U.S. Geological Survey remains dedicated to it original mission to collect, analyze, interpret, publish, and disseminate information about the natural resources of the Nation. The results of U.S. Geological Survey investigations are published in its scientific reports and in its topographic, geologic, and hydrologic maps. About 93,000 different maps and books are available for public use. A series of general-interest publications is available to inform the public about U.S. Geological Survey activities. Research results and investigations are also published in journals of technical and scientific organizations and in publications of cooperating Federal and state agencies.

Hundreds of hours are spent annually by the Pennsylvania District responding to over 1,000 data and information requests. These requests are received from public officials at all levels of government, water management personnel, consultants, universities, industry, and the general public. In addition to providing information and materials for specific needs and making distribution of water-resource reports, district staff answer general questions on hydrology, water as a resource, and hydrologic mapping, as well as on the products, projects, and services of the Water Resources Division.

A listing of selected 1iterature on water resources in Pennsylvania is included in this report, beginning on page 37. 
PROJECT CHIEF: Clayton Kauffman

COOPERATOR(S): Multiple

PERIOD OF PROJECT: Continuous since June 1931

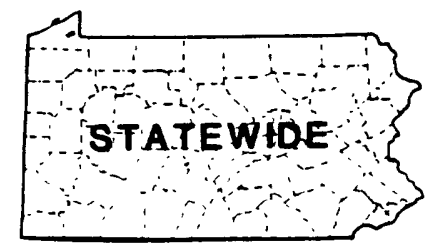

PROBLEM: Surface-water information is needed for purposes of surveillance, planning, design, hazard warning, operation, and management in water-related fields such as water supply, hydroelectric power, flood control, irrigation, bridge and culvert design, wildlife management, pollution abatement, flood-plain management, and water-resources development. To provide this information an appropriate data base is necessary.

OBJECTIVE: A. To collect surface-water data sufficient to satisfy needs for current-purpose uses, such as 1) assessment of water resources, 2) operation of reservoirs or industries, 3) forecasting, 4) disposal of wastes and pollution controls, 5) discharge data to accompany water-quality measurements, 6) compact and legal requirements, and 7) research or special studies. B. To collect data necessary for analytical studies to define for any location the statistical properties of, and trends in, the occurrence of water in streams, lakes, estuaries, etc., for use in planning and design.

APPROACH: To provide supervision of surface-water hydrologic data network and to insure collections and analyses of data are made by standardized methods, such as those described in the series, "Techniques of Water Resources Investigations of the United States Geological Survey." Data and information requests from cooperators, consultants, the public, and the academic community are coordinated at the District level.

PROGRESS: Hydrologic data for continuous record, reservoir, and partial-record surface-water stations were published. A special project to upgrade and expand flood forecasting capabilities in the Susquehanna River basin was undertaken. The current data network consists of 526 active sites, 243 continuous recording and 283 others.

PLANS: We will continue to collect and publish surface-water data and maintain data base. 
PROJECT CHIEF: Albert E. Becher

COOPERATOR(S): PaDER, Bureau of Topographic and Geologic Survey, Bureau of Water Resources

Management, Chester County Water Resources Authority

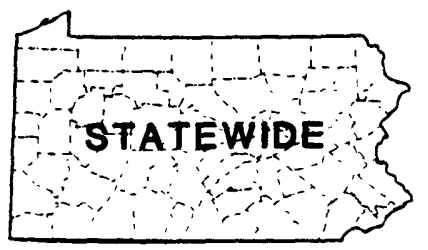

PERIOD OF PROJECT: Continuous since January 1931

PROBLEM: Long-term water-level records are needed to evaluate the effects of climatic variations on the recharge to and discharge from the ground-water systems, to provide a data base from which to measure the effects of development, to assist in the prediction of future supplies, and to provide data for management of the resource.

OBJECTIVE: To collect water level data sufficient to provide a minimum longterm data base so that the general response of the hydrologic system to natural climatic variations and induced stresses is known and potential problems can be defined early enough to allow proper planning and management. To provide a data base against which the short-term records acquired in areal studies can be analyzed. This analysis must (1) provide an assessment of the ground-water resource, (2) allow prediction of future conditions, and (3) provide the data base necessary for management of the resource.

APPROACH: Data will be collected and processed in each of the Subdistrict offices.

PROGRESS: All ground-water network data were collected on schedule and published by the Subdistrict offices. Transfer of ground-water data to Ground-Water Site Inventory (GWSI) was continued. The present network consists of 62 continuous recording sites.

PLANS: We will continue to operate the network and transfer data into GWIS. 


\section{WATER-QUALITY STATIONS (PA003)}

PROJECT CHIEF: David E. Click

COOPERATOR(S): Multiple

PERIOD OF PROJECT: Intermittent since August 1949

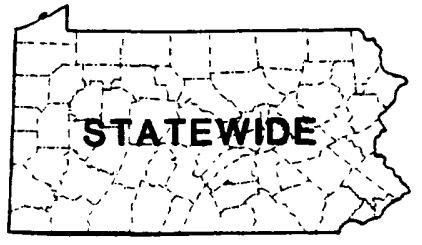

PROBLEM: Water-quality data are needed for surveillance, planning, design, and management of water resources. Water-quality problems can affect industries, water-treatment facilities, and the individual consumer. To provide the appropriate information, a data base is necessary.

OBJECTIVE: To collect water-quality data sufficient for current uses, such as (1) assessment of water resources, (2) operation of reservoirs, and (3) research or special studies. To collect data necessary for planning and management and for analytical studies to define the statistical properties of spatial and temporal trends in the quality of streams, lakes, and estuaries.

APPROACH: Water samples are collected periodically and analyzed in the U.S. Geological Survey Central Laboratory. At some sites, temperature, dissolved oxygen, $\mathrm{pH}$, and specific conductance are monitored continuously. The operation of the network provides chemical concentrations and loads as required by water planning and managing agencies.

PROGRESS: Data collection and analysis continued.

PLANS: Continue collection of water-quality data at network sites and publish results in the annual Water-Data Reports. 
PROJECT CHIEF: David E. Click

COOPERATOR(S): None

PERIOD OF PROJECT: Intermittent since October 1948

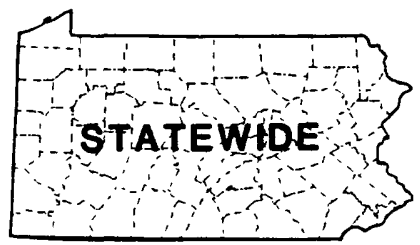

PROBLEM: Transported sediments deposit in reservoirs and harbors, contaminate water supplies, adversely affect machinery, and cause fishery problems. On the other hand, sediment is needed to maintain beaches, control algae, and remove toxic chemicals from the water. Sediment data are necessary for erosion studies, reservoir design, dredging scheduling, and drinking-water standards. A network of sediment stations is needed to provide a data base for proper water-resources management.

OBJECTIVE: To collect sediment data sufficient for current uses such as (1) reservoir design, (2) water-quality standards, (3) pollution controls, (4) erosion assessment, (5) water-resource management, (6) dredging, and (7) research or special studies. To collect data necessary for analytical studies to delineate the effects of land use, such as highway construction, mining, and urbanization. To describe the effects of sediment on water chemistry and to assess spatial and temporal trends.

APPROACH: Suspended-sediment samples are collected and loads calculated by methods described in the series "Techniques of Water Resources Investigations of the United States Geological Survey." Automatic samplers are used at some locations and coal-separation techniques are used to determine effects of coal mining.

PROGRESS: Data collection and analysis continues.

PLANS: Continue data collection at the network stations. Construct two stations on Swatara Creek equipped with stage recorder, flow-through monitor, automatic-pumping sampler and Data Collection Platform. 


\section{SUSQUEHANNA FLOOD FORECASTING SYSTEM IMPROVEMENT PROGRAM}

PROJECT CHIEF: Robert Hainly

COOPERATOR(S): NOAA, PaDER

PERIOD OF PROJECT: February 1986 to September 1990

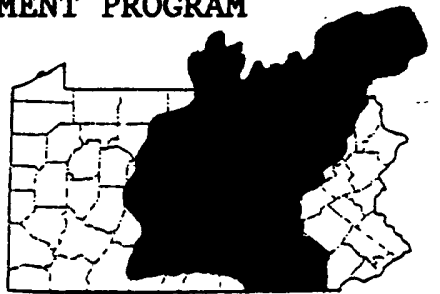

PROBLEM: Average annual flood damages in the Susquehanna River basin are about $\$ 82,500,000$ (1984 dollars). Studies indicate that improved flood warning coupled with various preparedness measures can reduce damages by 10 to 15 percent.

OBJECTIVE: To upgrade the data collection network in the basin as part of the overall improvement program which also includes improved hydrologic forecasting capability, enhanced forecast and warning dissemination, and improved radar coverage.

APPROACH: Provide additional data to the Middle Atlantic River Forecast Center by constructing 19 new stream gages and installing 33 air temperature and 61 precipitation gages in the basin. Accomplish more timely collection of data by installing satellite telemetry DCPs (Data Collection Platforms) and landline telemetry (telephone modems) on 39 stream, 33 air temperature, and 78 precipitation gages, and improving the Harrisburg satellite receive site by upgrading computer capabilities and providing an uninterruptible power supply and spare components to reduce down time.

PROGRESS: Al1 instruments have been purchased. Nine of the 19 new stream gages have been constructed and are transmitting data. Installation of equipment at al1 20 of the existing stream gages have been completed. Six of the 78 rain gages originally planned for installation have been dropped from the program. of the remaining 72 rain gages, 58 have been installed and are transmitting data. Twenty-seven of the 33 air-temperature sensors have been installed and are operating. Eighty percent of the phone line installations have been completed.

PLANS: Continue the same as in the past until all elements of the project are completed. In 1989, the following progress is expected: complete installation of 5 new stream gages, 9 rain gages, 3 air-temperature sensors, and 14 phone lines. The project will be about 90 percent complete. 
PROJECT CHIEF: Thomas F. Behrendt

COOPERATOR(S): FEMA

PERIOD OF PROJECT: July 1972 to September 1989

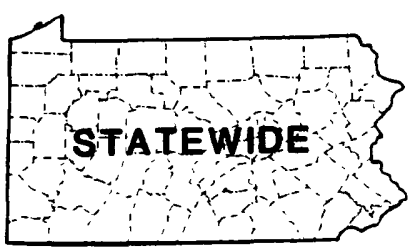

PROBLEM: The National Flood Insurance Act of 1968 and the Flood Disaster Protection Act of 1973 provides for the operation of a flood insurance program. FEMA needs flood studies in selected areas to determine applicable flood insurance premium rates.

OBJECTIVE: To conduct the necessary hydrologic and hydraulic evaluations and studies of areas assigned by FEMA and to present the results in an appropriate format.

APPROACH: To conduct the necessary evaluations or to conduct surveys by ground or photogrammetric methods. Determine flood-discharge frequency relationships using local historical information, gaging station records, or other applicable information. Determine water-surface profiles using step-backwater models or other acceptable methods and furnish the results in reports prepared to FEMA specifications.

PROGRESS: Of the 96 Less Detailed Studies (LDS) remaining for completion at the beginning of the fiscal year, 92 were reviewed, revised as necessary, and all but 8 were submitted to FEMA. Two new Limited Map Maintenance (LMM) studies were added and draft reports were prepared. Additional final meetings were held with officials of studied communities, bringing the total final meetings to 125.

PLANS: Submit remaining 8 LDS's, of the original 196, as well as the 2 LMM's, to FEMA. Complete surveys, calculations, and draft reports for one new LDS and five new LMM's and submit results to FEMA by June 1, 1989. Continue with final meetings as they are scheduled by FEMA. 
PROGRAM FOR THE COLLECTION, STORAGE, AND RETRIEVAL OF

WATER-USE DATA IN PENNSYLVANIA (PA007)

PROJECT CHIEF: Scott A. Hoffman

COOPERATOR(S): PaDER, Bureau of Water Quality

Management

PERIOD OF PROJECT: January 1981 to September 1991

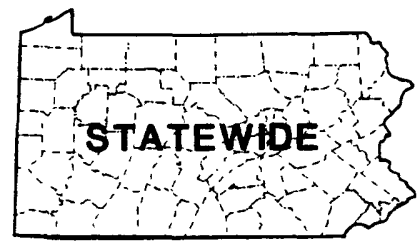

PROBLEM: Waters in Pennsylvania are under stress to supply increasing demands for domestic, industrial, agricultural, and other uses. Competition for water dictates that available supplies be matched with uses most beneficial to the common good. Information has been collected for many years describing quantity and quality of available water. Information on use of water is needed also if the best decisions are to be made about critical water problems such as resource allocations, water-quality residuals, environmental impact, and energy development.

OBJECTIVE: To provide water-use information for the optimum utilization and management of the State's water resources for the overall benefit of the people of Pennsylvania and the United States. This program will modify and improve the State's existing system to collect, store, and disseminate water-use data to complement data on availability and quality of the State's water resources. The new system will be responsive to the data needs of local users, the U.S. Geological Survey, and other federal agencies.

APPROACH: Responsibilities will be divided between the cooperator and the U.S. Geological Survey to reflect the most efficient means of meeting the objectives of the program. Direction, management, and standards development to meet the National needs will be the responsibility of the U.S. Geological Survey. Field activities for the acquisition and storage of the data at the state level will be the primary responsibility of the PaDER, Bureau of Water Resources Management.

PROGRESS: Full-time water-use chief position filled; training in INFO and GIS completed; training at water-use meeting completed.

PLANS: Begin cooperative work on industrial water-use data with State (PaDER); become familiar with U.S. Geological Survey water-use computer programs and State water-use programs; submit a product to cooperator on industrial data. 
PROJECT CHIEF: Patricia L. Lietman

COOPERATOR(S): PaDER, Bureau of Water Quality

Management

PERIOD OF PROJECT: January 1981 to September 1991

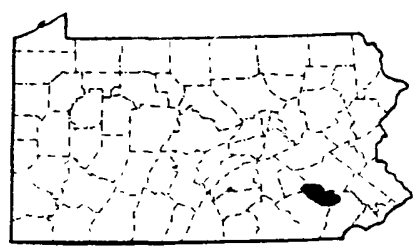

PROBLEM: The surface and ground waters of the Upper Conestoga River basin, Lancaster County, are degraded by runoff and infiltration from intensive agriculture. Suspended sediment, phosphorus, and nitrate concentrataions, and bacteria counts are excessive in many parts of the basin, particularly those areas underlain by carbonate formations. The basin is 1 of 12 watersheds designated for implementation of Best Management Practices (BMP's) as part of the National Rural Clean Water Program (RCWP). Minimal data are available to assess the effectiveness of BMP's in controlling agricultural runoff and infiltration to the ground-water system. Virtually no data are available to assess the effects of BMP installation on water chemistry, particularly bacteria and nitrate.

OBJECTIVE: To define the surface- and ground-water quality in the Upper Conestoga River basin. To evaluate changes in runoff and surface- and groundwater quality caused by the installation of BMP's at two small field sites (about 50 acres each) and in one small watershed (about 5 square miles) in the basin.

APPROACH: Nutrient and herbicide concentrations in ground and surface water and suspended-sediment concentrations in surface water will be monitored before and after the implementation of BMP's at three sites. Two field sites and a small watershed will be monitored for water quality through the use of continuousrecord or partial-record gaging stations, automatic samplers, recording rain gages and wells. Statistical analysis and hydrologic models will be used to evaluate changes in water quality.

PROGRESS: Preliminary data analysis shows: (1) at Field Site 1 , nitratenitrogen concentrations have significantly increased from pre- to post-BMP at four of six ground-water monitoring sites, no significant change occurred at the other two sites; in surface runoff, mean storm concentrations of suspended sediment significantly decreased and mean storm concentrations of nitratenitrogen significantly increased from pre- to post-BMP periods; (2) at Field Site 2, nitrate-nitrogen concentrations significantly decreased at three groundwater monitoring sites, significantly increased at one site, and did not significantly change at the four other sites from pre- to post-BMP periods; however, decreases at two of the three sites are thought to be caused by circumstances other than BMP implementation; (3) at the Small Watershed site, no significant changes in nutrient concentrations in base flow have been measured between preand post-BMP periods. A journal article has been published in Ground Water Monitoring Review, Winter 1989. One report, U.S. Geological Survey Open File Report 88-96, has been published and one report is in the review process.

PLANS: Some form of post-BMP monitoring will continue at all sites. Two reports will be written and entered into the review process. 


\section{EFFECTS OF ACID RAIN ON THE WATER QUALITY OF LAUREL RIDGE,}

SOMERSET COUNTY, PENNSYLVANIA (PA145)

PROJECT CHIEF: Emitt C. Witt

COOPERATOR(S): USEPA

PERIOD OF PROJECT: April 1983 to September 1993

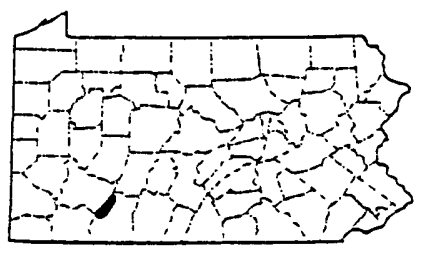

PROBLEM: Headwater streams in portions of Somerset County, Pennsylvania are extremely sensitive to acidic deposition and chemical weathering of soils. As a result of this situation there is possible damage to fish and other components of the aquatic ecosystem.

OBJECTIVE: To determine the effects of acid deposition on the chemistry of a poorly buffered headwater stream.

APPROACH: A single 3.45-square mile forested basin has been selected for monitoring over a 10-year period. Data collection includes continuous streamflow monitoring and monthly base flow water-quality sampling. At the completion of the proposed data collection period, interpretation will involve the application of nonparametric statistics to determine trends in water quality.

PROGRESS: Completed 62 months of base-flow water-quality sampling. Because of erosion of the side walls of the concrete weir, a new stage-discharge relationship has been developed. Both water-quality and surface-water data are published annually in the U.S. Geological Survey, Water Data Report for Pennsylvania.

PLANS: Continue monthly base flow water-quality sampling at the study site. 


\section{GROUND-WATER QUALITY ASSESSMENT OF WARREN COUNTY, PA (PA157)}

\section{PROJECT CHIEF: Theodore Buckwalter}

COOPERATOR(S): PaDER, Bureau of Topographic and Geologic Survey, Warren County Commissioners

\section{PERIOD OF PROJECT: July 1984 to December 1988}

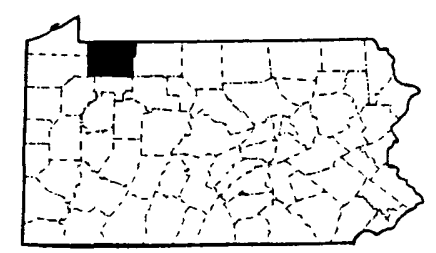

PROBLEM: Ground water is the predominant source for domestic and municipal water supplies for Warren County. Degradation of shallow ground water by industrial wastes and oil and gas development has been documented in selected areas of the county. Information concerning the quality and quantity of the ground-water resources of the county is needed for management and resource development.

OBJECTIVE: Assess the geohydrologic system in the study area. Estimate at selected sites the areal extent of ground-water degradation resulting from oil and gas development and from disposal of other hazardous substances. Provide data on the physical/chemical character of the contaminants; assess the hydraulic properties of the rock containing the contaminants.

APPROACH: Perform literature review. Conduct well inventory and ground-water quality sampling throughout Warren County to assess hydraulic properties and quality of major aquifers. Install observation wells. Perform aquifer tests and geophysical logging. Design and conduct test drilling program. Prepare report for publication in Pennsylvania Geological Survey Water Resource Report Series.

PROGRESS: Three aquifer tests, including water-quality sampling were completed. At Chapman State Park, a 48-hour pumping test confirmed the adequacy of the existing pumping well to provide for the water-supply needs of the Park. As a follow-up to August 1987 sampling, 17 domestic wells in a housing development were resampled in November 1987 for arsenic and barium. The laboratory results confirmed the findings in August with all 17 wells exceeding the USEPA drinking water standards for arsenic and (or) barium. Pennsylvania Governor Casey, on June 8, 1988, signed legislation for a low-interest loan for the extension of public water lines to the housing development. Text and tables for the basic data report are near completion. For the final report, introductory and hydrologic balance sections are written and typed.

PLANS: Complete first draft of basic data report. Perform revisions resulting from reviews. With Bureau of Topographic and Geologic Survey author, complete first draft of final report. 


\section{EVALUATION OF AGRICULTURAL BEST MANAGEMENT PRACTICES AND OTHER INNOVATIVE METHODS OF CONTROLLING NUTRIENT DISCHARGES IN THE LOWER SUSQUEHANNA RIVER BASIN (PA158)}

PROJECT CHIEF: David K. Fishe1

COOPERATOR(S): SRBC

PERIOD OF PROJECT: October 1984 to September 1990

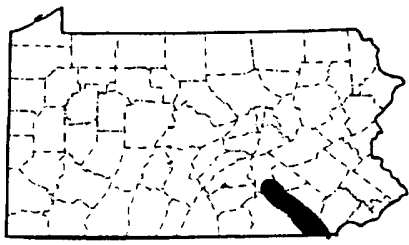

PROBLEM: The PaDER and PDA are developing a nonpoint-source control program for agriculture in the lower Susquehanna River basin. In addition to traditional practices, new practices or alternate schemes will be utilized to limit the nutrients transported from farms. There is no program that evaluates the impact of these practices on water quality in areas underlain by noncarbonate rocks in the lower Susquehanna River basin.

OBJECTIVE: To document the water quality of surface runoff and base flow from small agricultural watersheds and to evalute the effectiveness of agricultural best management practices in controlling nutrient and suspended-sediment discharges in basins underlain by noncarbonate rocks.

APPROACH: The variability and trends in surface runoff and base-flow water quality based on precipitation and farming practices will be documented at two small watersheds underlain by noncarbonate rock 2 years before and 2 years after practice implementation. The effects of the practices on sediment and nutrient discharges will be measured using statistical trend analysis and data may be used to model the effectiveness of the practices using the Chemical Runoff and Erosion from Agricultural Management Systems (CREAMS) or Hydrologic Simulation Program-Fortran (HSPF) models. Results will be compared to determine the relative influences of physiography, geology, soils, land use, precipitation and installed practices on water quality.

PROGRESS: Water-quality samples, soil samples, land-use data, and precipitation data continue to be collected at two small agricultural watersheds. Approximately 50 percent of animal units have been reduced at the York County site, however no changes in water quality have been observed as yet. Draft of the pre-management data report for the York County site is nearly completed.

PLANS: Pre-management data collection will be completed at the Adams County site. Attempts to model the York County site will continue. A draft of the report characterizing the Adams County site will be prepared. An evaluation of the effects of the reduction in animal units at the York County site will begin. 
PROJECT CHIEF: Lloyd A. Reed

COOPERATOR(S): SRBC

PERIOD OF PROJECT: October 1984 to September 1990

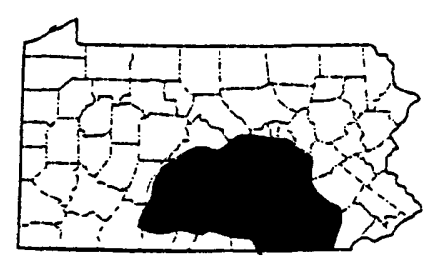

PROBLEM: The lower Susquehanna River basin has been identified as being the major nutrient contributor to the upper Chesapeake Bay. The nutrients, nitrogen and phosphorus, which contribute to algal growth and resultant water-quality degradation, have been related to accelerated eutrophication of the Chesapeake Bay.

OBJECTIVE: To characterize the nutrient discharge from the Susquehanna River and its major tributaries south of Harrisburg, Pennsylvania to the Chesapeake Bay.

APPROACH: Will determine (1) relative contribution of nutrients and suspended sediment from individual tributaries, (2) seasonal variation in nutrient and suspended-sediment discharge, (3) distribution of nutrient discharge between dissolved and pariculate phases during storm runoff and base flow, and (4) annual contribution of point-sources to the total nutrient discharge.

PROGRESS: Annual loads of suspended sediment and nutrients were computed for 1985 and 1986. Base-flow samples were collected monthly and storm samples were collected.

PLANS: Compute loads of sediment and nutrients for 1987 and 1988 . Continue data collection and prepare a progress report. 


\section{WATER-QUALITY EFFECTS OF THE APPLICATION OF SEWAGE SLUDGE ON COAL SURFACE MINES (PA160)}

PROJECT CHIEF: Charles A. Cravotta, III

COOPERATOR(S): PaDER, Bureau of Surface Mine

Reclamation

PERIOD OF PROJECT: May 1986 to September 1989

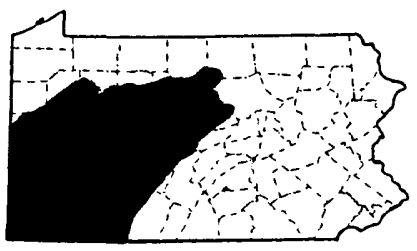

PROBLEM: Information is needed on the water-quality effects associated with the use of urban sewage sludge in the reclamation of surface mines in the bituminous coal fields of Pennsylvania. The possibility of a reduction in acid mine drainage and the potential for additional water-quality problems, including the migration of metals from sludge, are of primary interest.

OBJECTIVE: To evaluate the water-quality effects of the application of urban sewage sludge at representative surface coal mines.

APPROACH: Two surface mines will be selected for study. Each site will be instrumented with wiers, wells, and lysimeters for water-quality and other hydrologic monitoring. One of the mines will not be reclaimed with sludge and will serve as a control site for background data. The other mine site will be reclaimed with sewage sludge. Monitoring will continue at both sites for approximately $2 \frac{1}{s}$ years following reclamation.

PROGRESS: Continued collection of water-quality and other hydrologic data from surface and subsurface at two mines in Clarion County. Database is being updated continually in QWDATA. Preliminary statistical analysis and geochemical evaluation completed and reported in a presentation at the U.S. Geological Survey, WRD Northeast Region Ground-Water Flow and Quality Conference at Niagara Falls, NY.

PLANS: Continue to collect water quality and other hydrologic data. Write introductory part of final report and begin preliminary data evaluation. 
PROJECT CHIEF: Donald R. Williams

COOPERATOR(S): PaDER, Bureau of Topographic and Geologic Survey, Indiana County Commissioners

PERIOD OF PROJECT: May 1986 to September 1989

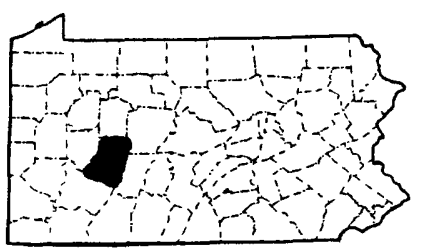

PROBLEM: Indiana County, in 1984, produced 12 million tons of bituminous coal, the largest county production in Pennsylvania. Eighty-four percent of this production was from underground mines. The impacts of mining on the water resources include acid mine drainage, which affects water quality, and the draining of shallow aquifers by subsurface mining, which affects ground- and surface-water quantity. Petroleum-production activities also have affected the surfaceand ground-water quality throughout the county. Some ground-water samples collected from northern Indiana County wells had chloride concentrations greater than $250 \mathrm{mg} / \mathrm{L}$ and concentrations of total dissolved solids as high as $1890 \mathrm{mg} / \mathrm{L}$. From 1979 to 1982, Indiana County had the highest number of gas wells drilled annually in the State, averaging 400 wells per year. Because coal mining continues to be active in the county and petroleum production is on the increase, county residents are concerned deeply about further effect of these activities on the water resources.

OBJECTIVE: (1) to appraise the water resources of Indiana County, (2) determine the effects of surface and subsurface mining on both the surface- and groundwater quantity and quality, and (3) determine the effects of gas well drilling on the surface- and ground-water quality.

APPROACH: About 400 water wells will be inventoried throughout the county. Of special interest will be the aquifer systems overlying active underground mining and areas where there has been a sharp increase in petroleum exploration. About 20 observation wells will be equipped with continuous water-level recorders in active mining areas, in non-mining areas, and in areas where petroleum production has increased. Aquifer tests will be done on the bedrock aquifers to analyze the variation of hydraulic properties with depth and between areas mined and unmined. Water samples will be collected at about 150 wells to determine ground-water quality. Six stream-gaging stations currently in operation in the county will be a part of the data-collection network and three additional stream gages will be constructed. Approximately 25 additional intermittent surfacewater sites will be established throughout the county. About six mass-sampling water-quality runs will be conducted at all of the surface-water sites during base-flow conditions. 
PROGRESS: About 250 wells and 20 springs were inventoried. About 150 well samples and 20 spring samples were collected for laboratory analyses. Three base-flow sampling runs were completed at the 31 surface-water sites. Three base-flow seepage runs were conducted in the mined Cherry Run basin and the unmined South Branch Plum Creek basin. Geophysical logging was conducted at 10 observation well sites. Aquifer tests were completed at nine observation well sites. Packer testing was conducted at the test well site in north central Indiana County where there is a well nest of six observation wells. The 24 continuous recording data-collection sites were kept fully operational throughout the year.

PLANS: The data-collection phase of the project is completed. All surfacewater, ground-water, and water-quality data will be compiled and reported in a basic data report for Indiana County. Writing will begin on the final interpretive report. Data collected for the 1988 water year will be compiled and published in the annual Water Resources Data Report for Pennsylvania, Volume 3. 
PROJECT CHIEF: Theodore Buckwalter

COOPERATOR(S): Erie County Department of Health

PERIOD OF PROJECT: October 1985 to September 1990

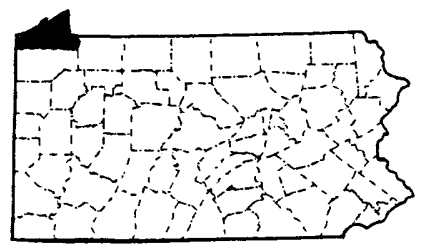

PROBLEM: The major water resource for the City of Erie, adjacent Millcreek Township, some other adjacent areas, North East, and Union City is surface water. The other parts of Erie County are dependent upon ground water. As a result of industrial and municipal waste disposal sites and petroleum exploration and production, the ground water is locally contaminated. This is measured by the exceedances of chemical constituents beyond the PaDER and USEPA safe drinking water limits, including: total-dissolved solids, lead, chloride, iron, and manganese. Two waste-disposal sites have been on the Super Fund list: Lord-Shope and Millcreek. The Erie County Department of Health knows of many other waste disposal sites, but does not know of the impact of these sites on municipal and domestic wells.

OBJECTIVE: (1) Determine ground-water quality of contamination sites; (2) develop a computer tabulation of the chemical constituent data of sites, and a map showing the location of the sites; (3) develop a ground-water resources map where abundant (long-term quantity) fresh ground water is available (assumed to be the buried channels of unconsolidated deposits); and (4) define land use as affecting ground-water quality (landfills and waste disposal sites are included in the group of contamination sites).

APPROACH: (1) Identify ground-water-quality problem areas; (2) develop groundwater-quality network and store data on computer for publication; (3) delineate buried channel unconsolidated deposits; and (4) determine ground-water flow characteristics.

PROGRESS: Acting project chief continued work activities: computer processing seismic-refraction surveys of 1987; performing seismic-reflection surveys of sites over buried channel deposits and morainal deposits (thicknesses of 100-200 feet) using 'Betsy Seisgun'; low flow measuring and sampling (54 sites); sampling of ground water for pesticides in agricultural land use areas; drilling of 17 observation wells; aquifer testing in beach deposits setting; inventorying water wells in areas of unconsolidated deposits greater than 100 feet. Analytical results compiled in cooperator's PC and tabulated. Observation-well network initiated.

PLANS: Evaluate seismic survey information; evaluate/continue observation well network (and perhaps expand); continue water well/inventory on a selected well basis; enter inventoried wells into GWSI; aquifer test in morainal deposits; evaluate existing water-quality information; annotate report outline. 
RADIUM AND RADON OCCURRENCE IN GROUND WATER OF THE CHICKIES FORMATION, SOUTHEASTERN PENNSYLVANIA (PA170)

PROJECT CHIEF: Lisa A. Senior

COOPERATOR(S): PaDER, Bureau of Topographic and Geologic Survey

PERIOD OF PROJECT: October 1986 to September 1988

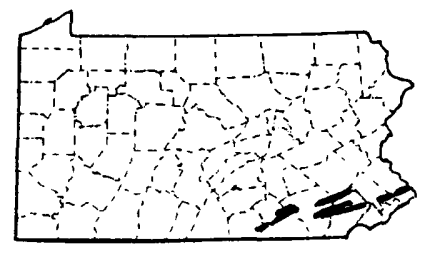

PROBLEM: Anomalous concentrations of radium are natura11y present in ground water within the Chickies Formation throughout southeastern Pennsylvania. These anomalous radium levels do not appear to be limited to any particular location in the Chickies Formation, and therefore may be related to unusual geochemical conditions within the formation. Data indicate that the radium and radon in solution seem largely confined to the Chickies Formation.

OBJECTIVE: (1) Identify the extent and magnitude of radium and radon anomalies in the Chickies Formation, (2) identify alternative water supplies in the Chickies for those areas where the maximum contaminant level of radium or radon in drinking water is exceeded, and (3) characterize the geochemical and hydrologic environment associated with elevated radium and radon concentrations.

APPROACH: The project is organized into three program elements beginning with the collection of available hydrologic and geochemical data. A field-sampling program will be designed and implemented after review of all available data. Data analysis and report writing constitute the final project element.

PROGRESS: Collected rock samples and logged wells drilled in the Chickies Formation to gain information about radioactivity of the aquifer. Finished collection of ground-water samples (70 additional samples) during summer 1988 . Submitted paper on radium and radon in the ground water of the Chickies Formation for inclusion in a U.S. Geological Survey Bulletin on radon in rocks, soils, and water.

PLANS: Review and analyze water chemistry in ground water and solid phase chemistry in rock. Preparation of final report. 


\section{AQUIFER CHARACTERISTICS OF THE ROCKS OF PENNSYLVANIA (PA171)}

PROJECT CHIEF: Dennis J. Low

COOPERATOR(S): PaDER, Bureau of Topographic and Geologic Survey

PERIOD OF PROJECT: January 1987 to September 1989

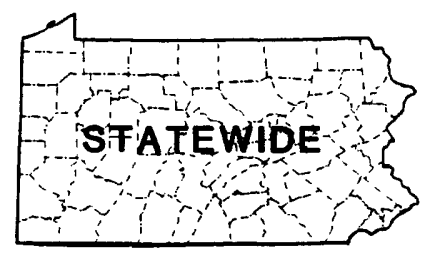

PROBLEM: Information on the aquifer characteristics of the rocks of

Pennsylvania is needed for proper resource development, management, and protection of sensitive ground-water resources. A comprehensive summary of aquifer characteristics, supplemental to the State Geologic Maps and 7/2-minute quadrangle maps, would substantia11y augment the informational needs of state and Federal regulatory agencies, resource planners, public and private water suppliers, industrial users, and hydrogeologic consultants.

OBJECTIVE: To develop a comprehensive summary of the aquifer characteristics of the rocks of Pennsylvania including information on 1ithology, topography, and structure; well-yield; ground-water quality; and ground-water recharge, flow, and discharge.

APPROACH: The comprehensive summary will be developed by: (1) compilation of statewide and regional reports; (2) extrapolation of published detailed investigations; (3) analysis of well-yield and water-quality data from over 5,000 we11s, which are updated continuously and stored in GWSI and WATSTORE data bases of the U.S. Geological Survey; (4) analysis of borehole-geophysical data on file with the U.S. Geological Survey; (5) review of aquifer-test data and wellinterference problems at selected sites on file with the SRBC and DRBC and other agencies; and (6) review of hydrogeologic and water-quality data at selected contamination sites on file with the PaDER and other agencies.

PROGRESS: Clean up of data base for Volume 1 report is completed. Numerous, but miscellaneous corrections must be made for the Volume 2 report. Report 1 outline has been approved by region; rough draft of Volume 1 was begun. Statistical packages have been written and edited for most of the variables involved in the study.

PLANS: Revise the Volume 1 report and transmit for Director's approval. Finish clean up of database for Volume 2 and begin rough draft. Continue clean up of database for Volume 3 . 
GROUND-WATER RESOURCES OF CHESTER COUNTY, PENNSYLVANIA (PA172)

PROJECT CHIEF: Ronald A. Sloto

COOPERATOR(S): Chester County Water Resources Authority

PERIOD OF PROJECT: October 1987 to September 1990

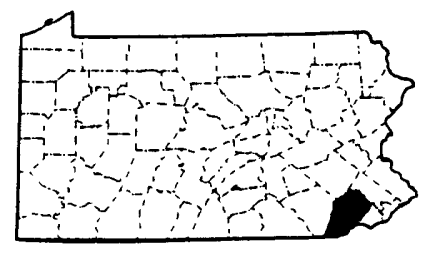

PROBLEM: Chester County is undergoing rapid growth and urbanization because of close proximity to Philadelphia. Ground water is the only source of water supply for most of the county. An assessment of the ground-water resource is needed because of increasing demand for ground water.

OBJECTIVE: To appraise the ground-water resources of Chester County.

APPROACH: Available data on ground-water quantity and quality will be summarized; aquifer and well-construction data will be analyzed statistically; detailed water budgets will be prepared; a comprehensive bibliography will be prepared.

PROGRESS: Report writing started. Statistical analysis of aquifer characteristics, water-bearing zones, and water-quality data completed. Preliminary water budget prepared. Water-level data base cleaned up. Hydrograph separations completed.

PLANS: Complete report and transmit for colleague review. 
PROJECT CHIEF: James I. Samms, III

COOPERATOR(S): U.S. Office of Surface Mining;

PaDER, Bureau of Mining and Reclamation

PERIOD OF PROJECT: October 1987 to September 1990

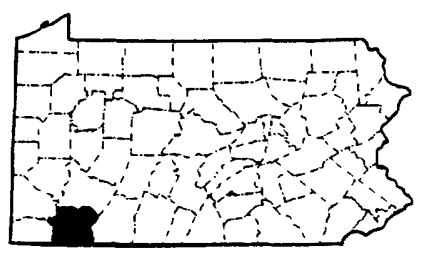

PROBLEM: PaDER, Bureau of Mining and Reclamation (BMR), is required by the Surface Mining Control and Reclamation Act (SMCRA) of 1977 to evaluate each mine permit application in light of its cumulative hydrologic impacts on the hydrologic system. Hydrologic models could serve as an objective tool in this type of evaluation. The accuracy and tranferability of models to ungaged watersheds must first be determined using gaged watersheds.

OBJECTIVE: Evaluate the transferability of model parameters from a model deve1oped for determining the effects of mining on Stony Creek basin to a model developed for the Poplar Run basin.

APPROACH: (1) Calibrate and verify the Hydrologic Simulation Program-FORTRAN (HSPF) model of the Stony Fork watershed. (2) transfer parameters from the Stony Fork model to an HSPF model of Poplar Run. (3) compare output of the Poplar Run model to observed data, and (4) report findings.

PROGRESS: Surface-water quality and quantity data were collected in the Poplar Run and Stony Fork watersheds for use in calibrating an HSPF model. Several calibration runs of the Stony Fork basin have been completed. Flow duration curves of actual streamflow data from the Stony Fork basin and model streamflow data have been compared.

PLANS: Continue data collection in both basins. Complete the hydrologic calibration of the Stony Fork and Poplar Run basins. 
PROJECT CHIEF: Kevin M. Kostelnik

COOPERATOR(S): U.S. Office of Surface Mining

PERIOD OF PROJECT: October 1987 to September 1992

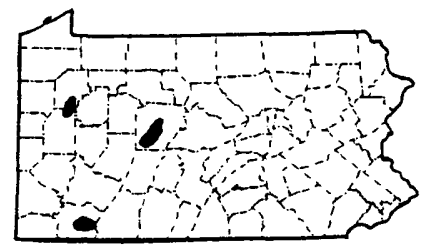

PROBLEM: The PaDER, Bureau of Mining and Reclamation is responsible for approving mine applications and plans in Pennsylvania. Often there are few available data and little time to collect and analyze data, and, therefore, insufficient information is available for making management decisions. PaDER needs a base of hydrologic data from many small (20-50 $\mathrm{mi}^{2}$ ) watersheds throughout the coal fields so that when they receive a mine application, they can immediately evaluate the areal water quality and then place their efforts into specific areas of study that will provide more detailed information for the final decision.

OBJECTIVE: To provide a summary of hydrologic data from small watersheds in the coal fields of Pennsylvania to PaDER for use in the mine-permit appraisal process.

APPROACH: Four watersheds will be selected for study each year. A minimum of 10 miscellaneous surface-water sampling sites and one continuous-recording gage site will be selected for each watershed. The miscellaneous sites will be visited quarterly; the gaged sites monthly. Discharge, field water-quality parameters, major ions, selected metals, and suspended sediment will be measured. At each gaged site, $\mathrm{pH}$, specific conductance, and water temperature will be recorded continuously. Each year, new watersheds will be selected and the previously studied watersheds abandoned. While data are being collected at the second set of watersheds, the data from the first set will be summarized.

PROGRESS: Three small watersheds, Little Clearfield Creek, Little Scrubgrass, and Meadow Run, were studied this year. A continuously recording gage was installed and 14 to $17 \mathrm{miscellaneous} \mathrm{sampling} \mathrm{sites} \mathrm{were} \mathrm{selected} \mathrm{at} \mathrm{each}$ watershed. Measurements of discharge were made and water-quality samples were collected quarterly at all sites and during various hydrologic conditions. These hydrologic data have been reviewed and are being summarized.

PLANS: Three or four new watersheds will be selected for a one-year waterquality investigation. All gaging equipment will be relocated to these new watersheds from the previously studied watersheds. Approximately 15 miscellaneous sites will be selected for quarterly water-quality sampling. Data collected will be evaluated, summarized, and presented to the cooperator. 
PROJECT CHIEF: Karen L. Vogel

COOPERATOR(S): Delaware Geological Survey, Chester County Water Resources Authority

PERIOD OF PROJECT: October 1987 to September 1991

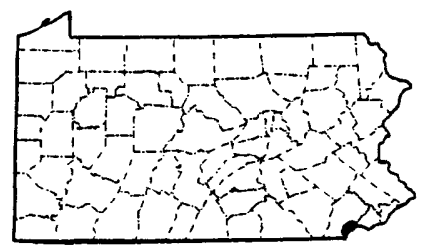

PROBLEM: Rapid urbanization in the Red Clay Creek basin has reduced groundwater recharge and increased water demand. County and local governments want to protect the base flow of streams and the quality of ground water while permitting additional ground-water development.

OBJECTIVE: Gain a detailed understanding of ground-water flow in the Red Clay Creek basin. Determine ground-water/surface-water relations. Determine a water budget for the basin. Document existing water-quality problems in the study area.

APPROACH: (1) Construct a stream-gaging station on the Pennsylvania-Delaware (PA-DE) border, (2) select 20 observation wells in the study area, (3) run 20 short-term aquifer tests and four 72-hour aquifer tests, (4) construct a watertable map of the study area, (5) develop a current water budget, and (6) construct a finite-difference digital ground-water flow model of the study area using the U.S. Geological Survey McDonald-Harbaugh modular model program.

PROGRESS: Constructed stream gage at Pennsylvania-Delaware border. Selected observation wells. Collected monthly water-level data. Selected rain-gage data-collection sites. Collected water-quality data for Pennsylvania part of basin. Report outline completed and approved.

PLANS: Literature search; install continuous water-level recorders; construct water-table map of area; conduct 20 short-term aquifer tests and four 72-hour aquifer tests. 
POTENTIAL IMPACTS OF CLIMATE CHANGE ON THE DELAWARE RIVER BASIN WATER RESOURCES - PENNSYLVANIA (PA181)

PROJECT CHIEF: Herbert N. Flippo, Jr.

COOPERATOR(S): Federal Program

PERIOD OF PROJECT: March 1988 to September 1990

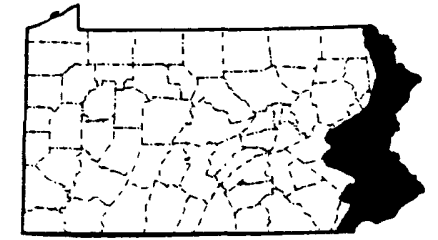

PROBLEM: General Circulations Models (GCM's), and other related studies, have postulated wide-spread climatic changes in the next several decades. The New Jersey District developed a project to assess, as a prototype study, the impacts of such changes on the water resources of the Delaware River basin. As a part of that effort, this project will develop an empirical daily-flows model to assess potential modifications of the basin's surface-water resources that may result from GCM-projected changes in precipitation and temperature.

OBJECTIVE: To assess the potential effects of climatic change on three important aspects of water availability in the Delaware River basin: (1) the New York City and other reservoir systems, (2) the ability to maintain the minimum instream flow requirements at Montague and Trenton, and (3) the upstream movement of saline water in the Delaware Estuary.

APPROACH: Develop empirically-based modules of the Hydrologic Simulation Program-Fortran (HSPF) for the basin. After development of a calibrated flowrouting module, use geographic/geologic information and climatic parameters in an optimization of daily-flow simulation. Physically-based modules (developed by others) will be substituted in the model if sensitivity testing proves them more useful than empirical techniques. Run the model with GCM-projected adjustments to climatic parameters and assess impacts on water availability.

PROGRESS: Project Chief attended training sessions and project planning meetings. Most of the F-table data for flow routing of major streamflows in the Delaware River basin was assembled for use in the HSPF model. A workstation for running the HSPF model was ordered.

PLANS: HSPF will be used to route flow in major streams. After a routing mode1 is developed, HSPF will be calibrated to simulate historical flow sequences and used to simulate flow sequences as affected by climatic changes forecasted by the General Circulation Model. 
EFFECT OF LAND USE AND ORGANOCHLORINE INSECTICIDES ON BENTHIC-

INVERTEBRATE DIVERSITY INDICES, CHESTER COUNTY, PENNSYLVANIA (PA182)

PROJECT CHIEF: Craig R. Moore

COOPERATOR(S): Chester County Water Resources Authority

PERIOD OF PROJECT: February 1988 to September 1990

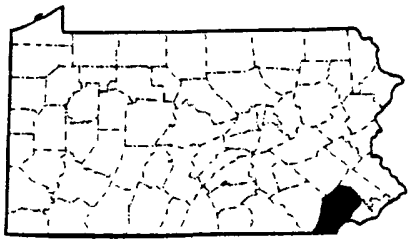

PROBLEM: A better understanding of the relationships among land use, changes in land use, organochlorine pesticide concentrations, diversity index trends, and water quality is needed so that Chester County planners and developers do not take actions that reverse the improving water-quality trends already observed by Moore (1987).

OBJECTIVE: Determine if land use practices and changes are related to the occurrence and concentration of organochlorine insecticides in stream-bottom sediments and to the diversity and changes in the diversity index of stream dwelling benthic-macroinvertebrates. Determine on a reconnaissance level, using available data, the distribution and transport of organochlorine insecticides in stream-bottom sediments in the Brandywine Creek basin.

APPROACH: The study will be done using available biological and chemical data. Only two additional sites will be sampled for stream-bottom materials. Land-use changes will be quantified in selected subbasins and related using nonparametric statistical tests to diversity index trends and concentration of organochlorine insecticides in stream-bottom sediments.

PROGRESS: Reconnoitered sediment core sample sites. Collected sediment cores for radionuclide dating and organochlorine insecticide analyses. Have completed land-use data compilation and started land-use data analysis. Completed report outline.

PLANS: Complete data analysis. Write report. 
GEOPHYSICAL STUDY OF USEPA SUPERFUND SITES IN PENNSYLVANIA, DELAWARE, MARYLAND, WEST VIRGINIA, VIRGINIA, AND WASHINGTON, D.C. (EPA REGION III) (PA183)

PROJECT CHIEF: Albert E. Becher

COOPERATOR(S): USEPA

MID-ATLANTIC STATES

PERIOD OF PROJECT: October 1988 to October 1990

PROBLEM: An understanding of the hydrogeology is essential for the design and implementation of efficient remediation protocols at USEPA Superfund sites. Geophysical studies can contribute detailed geologic and hydrogeologic information about a site.

OBJECTIVE: Collect borehole and surface geophysical data at USEPA Superfund sites. Provide information on the hydrogeology of aquifers at Superfund sites based on an interpretation of the geophysical and other available data.

APPROACH: At each site selected for study by USEPA, Region III, borehole or surface geophysical studies will be done as appropriate. For each site, USEPA will submit a request and "scope of work." A work plan and a quality assurance plan will then be provided to the USEPA project leader and approved by USEPA. USEPA will provide equipment decontamination procedures and health and safety information for each site. The data from each borehole or surface geophysical geophone spread will be analyzed separately and interpreted collectively with a11 site geophysical data and general information. A mounted Soporis digital geophysical logger with computer is available in the District. Seismic and electrical resistivity surface geophysical equipment are available to the District.

PROGRESS: New project.

PLANS: Complete surface and borehole geophysical studies on USEPA Superfund sites as requested. Studies have been requested for sites in Lebanon Co., PA, Albemarle Co., VA, and Chester Co., PA. Work plans, safety plans, and quality assurance/quality control plans will be prepared for these sites. 
PROJECT CHIEF: J. Kent Crawford

COOPERATOR(S): Federal Program

NATIONWIDE

PERIOD OF PROJECT: October 1988 to September 1989

PROBLEM: The National Water-Quality Assessment (NAWQA) Program is a perennial program of data acquisition, interpretation, and assessment of the Nation's water resources. For this program to be successful, it must go beyond previous water-quality monitoring efforts wherein various chemical constituents are monitored at somewhat regular intervals at fixed locations. Therefore, NAWQA will have innovative sampling strategies for chemical constituents and will include biological monitoring. However, no consensus has evolved as to which biological measures should be incorporated into NAWQA or how the chosen biological activities should be implemented. This project will address that problem by providing a design for using tissue analys is in NAWQA.

OBJECTIVE: To produce a protocol for using tissue analysis in NAWQA.

APPROACH: Development of the protocol document is viewed as a two-phase process. First, in Phase I, a draft protocol will be developed which will undergo intensive internal and external review. As a concensus is reached on the most appropriate plan for tissue analysis studies, then Phase II, a field test of the protocol, will be implemented at one or more of the NAWQA pilot study units. This project addresses only Phase I, development of the draft protocol. The first step in protocol development will be to define attainable objectives for the use of tissue analysis in NAWQA. Once objectives have been finalized, the protocol will be drafted, based on an extensive literature review, discussions with scientists within and outside the U.S. Geological Survey and possibly some field testing. The draft protocol will then undergo extensive review and coordination in an iterative process to arrive at a final plan.

PROGRESS: New project.

PLANS: Conduct literature review, confer with other scientists within and outside of U.S. Geological Survey, prepare draft protocol and modify draft based on extensive review process to arrive at final protocol document. 


\title{
USE OF MULTIPLE STABLE ISOTOPES TO DISTINGUISH SOURCES OF \\ NITROGEN CONTAMINATION IN THE SUSQUEHANNA RIVER BASIN, PENNSYLVANIA (PA185)
}

\author{
PROJECT CHIEF: Charles A. Cravotta III \\ COOPERATOR(S): PaDER, Bureau of Soil and \\ Water Conservation \\ PERIOD OF PROJECT: October 1988 to January 1990
}

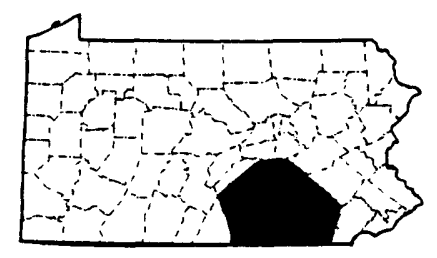

PROBLEM: A simple method is needed to distinguish the sources of nitrogen contamination in surface waters. Analyses of stable isotopes of carbon (C), nitrogen $(N)$, and sulfur (S) may prove useful for tracing sources with unique compositions.

OBJECTIVE: Characterize different nitrogen-source materials and nearby soils and stream waters by using stable $C, N$, and $S$ isotopes and then determine the relative contributions to the nitrogen load from different nitrogen sources in selected watersheds on the basis of the isotopic compositions.

APPROACH: The U.S. Geological Survey will (1) characterize the stable C, N, and $S$ isotopic and species concentrations of potential nitrogen sources, (2) evaluate the feasibility of using multiple isotopes to distinguish between various nitrogen sources, (3) evaluate the isotopic analyses of soil, stream water, and suspended sediment with respect to dominant land uses in several small, singlesource watersheds, (4) apply the isotopic technique to several larger, multiplesource watersheds to verify the method and estimate proportions of nitrogen loads from different sources, and (5) estimate the proportion of nitrogen loads entering the Susquehanna River.

PROGRESS: New project.

PLANS: Collect source-material (manure, human waste, precipitation) and soil, stream-water, and suspended-sediment samples for chemical and isotopic analysis. Evaluate data to determine relationship between source and soil/water composition. Estimate proportion of nitrogen loads from various sources in multiple-source watersheds. Write quarterly progress reports and partial draft interpretive report. 
Listed below are titles of recently completed projects. Reports for these projects are in various stages of preparation, but have not yet received Director's approval and therefore, have not been assigned a report number. Descriptions of these projects are contained in U.S. Geological Survey Open-File Report 87-475, Water-Resources Activities of the U.S. Geological Survey in Pennsylvania, 1986-87, Helm, R. E.

Appraisal of Water Resources and the Effects of Coal Mining on the Water Resources of Washington County, Pennsylvania (PA107)

Impacts of Surface Mining on Water Quality of the Stony Fork Watershed, Fayette County, Pennsylvania (PA124)

Application of Limestone Quarry Waste in the Abatement of Acidic Drainage from a Coal Strip-Mine Site (PA142)

Ground-Water Resources of Cambrian and Ordovician Carbonate Rocks in the Valley and Ridge Province in Pennsylvania (PA146)

A Model of Ground-Water Flow in the Carbonate Rock of the Little Lehigh Creek Basin, Lehigh County, Pennsylvania (PA148)

Determination of the Cumulative Impact of Acid Mine Discharges to the West Branch Susquehanna River between Curwensville and Renovo, Pennsylvania (PA150)

Ground-Water Flow Systems and Water Quality of the Gettsyburg Area, Pennsylvania (PA164)

Ground-Water Flow in the Carbonate Rock of the Valley Creek Basin, Chester County, Pennsylvania (PA165) 
The Water Resources Division of the U.S. Geological Survey is the Nation's lead agency in the collection of water data and the dissemination of information on water resources. The Division makes water data and information readily and equally available to water managers, policymakers, the scientific community, and the public in formats that meet their needs.

The U.S. Geological Survey has published the results of its studies for more than 100 years. The information is multipurpose and, after its initial use, becomes a basis for future resource evaluation and water-management decisions. The Water Resources Division releases its information through several publication series, explained below, and through computerized systems, accessible through NAWDEX and WATSTORE (see page 5).

A description of these publications series, the types of information presented in them and ordering information is given below.

Water Supply Paper--Significant interpretive results of hydrologic investigations that are considered to be of broad interest.

Professional Paper--Comprehensive or topical reports on any earthscience subject of interest to multi-discipline scientific audiences.

Bulletin--Significant interpretive results of earth-science investigations of broad interest, including computer applications.

Circular--Summaries of topical investigations or programs that are of short-term or local interest.

Map series, such as Hydrologic Investigations Atlas--Significant results of hydrologic investigations presented in map format.

Techniques of Water-Resources Investigations Report--Reports on methods and techniques used in collecting, analyzing, and processing hydrologic data for technically oriented audiences.

Geological Survey Yearbook--Significant activities of the Water Resources Division that are summarized each year for general audiences.

Water Resources Investigations Report--Comprehensive or topical interpretive reports, and maps mainly of local or shortterm interest, for interdisciplinary audiences.

Open-file book and map reports--Compilations of data and preliminary interpretive reports of limited interest, or reports awaiting formal publication that require interim release. 
Water-Data Report--Water year data on streamflow, ground-water levels, and quality of surface and ground-water for each state, Puerto Rico, Virgin Islands, and the Trust Territories.

National Water Conditions--A monthly news release that summarizes the national water situation for water-resources-oriented audiences.

With the exception of the "National Water Conditions," which is a form of news release, all the above publication series are listed in three catalogs-"Publications of the Geological Survey, 1879-1961", "Publications of the Geological Survey, 1962-1970", and "Publications of the Geological Survey, 1971 through 1981"--and in yearly supplements to these catalogs for 1982 through 1987.

As new publications are released, they are announced in a monthly list, "New Publications of the Geological Survey", to which a free subscription is available by writing to the U.S. Geological Survey, 582 National Center, Reston, VA 22092.

Many items of scientific interest are published in technical and scientific journals to make the information readily available to those in related fields of study. Other reports of local interest are published by cooperating State agencies and made available within the State.

A report,--U.S. Geological Survey Circular 900, "Guide to Obtaining USGS Information",--describes sources of U.S. Geological Survey information and shows in tabular form the types of U.S. Geological Survey products and where they are available. (see selow for ordering information)

\section{TO ORDER TEXT PRODUCTS}

Professional papers, bulletins, water-supply papers, techniques of water-resources investigations, water-resources investigations reports, circulars, publications of general interest (such as leaflets, pamphlets, booklets), single copies of the Earthquake Information Bulletin, Preliminary Determination of Epicenters, and some miscellaneous reports, including some from the foregoing series that have gone out of print at the Superintendent of Documents, are obtainable by mail from U.S. Geological Survey, Books and Open-File Reports, Federal Center, Building 41, Box 25425, Denver, CO 80225.

Certain U.S. Geological Survey reports, including most of the Water Resource Investigations (WRI) series released before 1982, "Water Resources Data - [State] Water year [year]" beginning with the 1975 issues, and many compilations of data, can be purchased only from the National Technical Information Service (NTIS). New U.S. Geological Survey reports that are available only from NTIS are cited in the monthly list, "New Publications of the U.S. Geological Survey." For information on obtaining these reports contact: National Technical Information Service, U.S. Department of Commerce, 5285 Port Royal Road, Springfield, VA 22161 (703) 737-4650. 


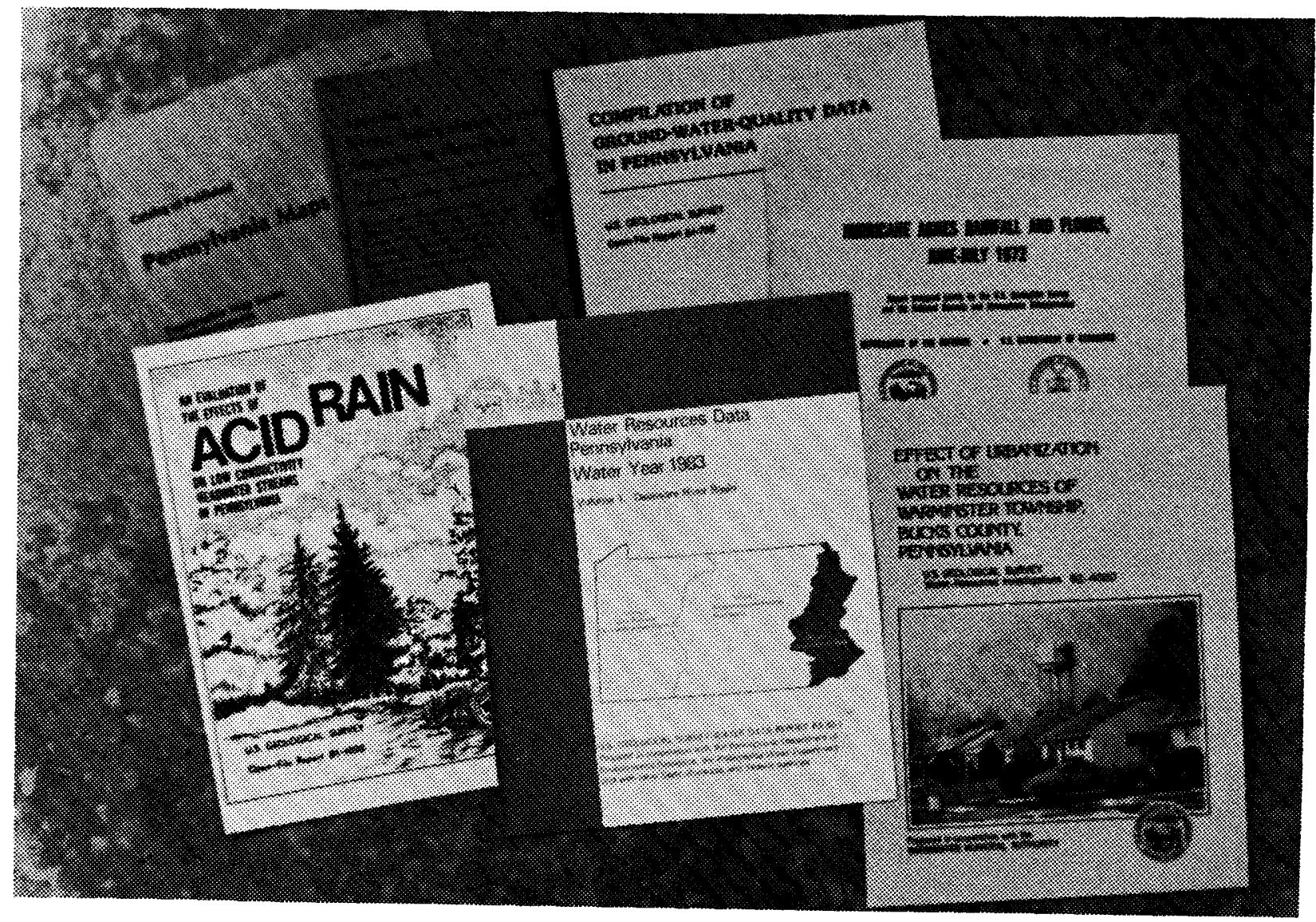

Because the number of publications pertaining to water resources in Pennsylvania is large, the publications listed herein were selected to show the types of information available to those interested in or in need of water facts. Many of these publications are available for inspection at the office listed on the front page of this report and at large public and university libraries. The publications are grouped as follows: I. Publications of the U.S. Geological Survey; II. Publications of State agencies prepared in cooperation with the U.S. Geological Survey; and III. Other publications, such as technical journals. 


\section{Publications of the U.S. Geological Survey}

General Information.--The U.S. Geological Survey announces all its publications in a monthly report "New Publications of the Geological Survey."

Subscriptions to this monthly listing are available upon request to the U.S. Geological Survey, 582 National Center, Reston, VA 22092. All publications are for sale unless specifically stated otherwise. Prices that are subject to change, are not included here. Prepayment is required and information on price and availability should be obtained before placing an order. The "U.S. Geological Survey Yearbook" provides a comprehensive description of the Federal Government's largest earth-science agency; copies may be purchased at the address where professional papers are sold. Summaries of research in progress and results of completed investigations are published each fiscal year in the professional paper series "Geological Survey Research." A pamphlet entitled "Geologic and Water-Supply Reports and maps for Pennsylvania and New Jersey," which includes reports of the geology and other water-resources reports, is available upon request to: Map Distribution Section, U.S. Geological Survey, Federal Center, Box 25286, Denver, CO 80225 (303) 236-7477.

Water Resources Information.--A monthly summary of the national water situation is presented in the "National Water Conditions." Records of streamflow, groundwater levels, and quality of water were published for many years as Geological Survey water-supply papers as explained below.

Streamflow records.--Records of daily flows of streams prior to 1971 were published in the Water-Supply Paper series "Surface-Water Supply of the United States," which was released in numbered parts as determined by natural drainage basins. Until 1961, this was an annual series; monthly and yearly summaries of these data were compiled in two reports: "Compilation of Records of Surface Waters of the United States through 1950," and "Compilation of Records of Surface Waters of the United States, October 1950 to September 1960." For the period 1961-1970, 5-year compilations were published. Data for Pennsylvania are published in Parts 1, 3, and 4. Daily streamflow records also were published on a State-boundary basis during the period 1961-74.

Ground-water records.--Ground-water levels and artesian pressures in observation wells prior to 1975 were reported by geographic areas in a 5-year Water-Supply Paper series. Data for Pennsylvania are in "Ground-Water Levels in the United States, Northern States."

Quality-of-water records.--Data on quality of surface water prior to 1971 were published annually in the Water-Supply Paper series "Quality of Surface Waters of the United States," which also was released in numbered parts as determined by natural drainage basins. Data for Pennsylvania are in Parts 1,3 , and 4. For water years 1964-74, these data also were released annually on a State-boundary basis.

Data reports covering the years 1971 through 1974 were published by the Geological Survey and archived by National Technical Information Service, and were retroactively numbered and included in the state water-data report series. 
Beginning with the 1975 water year, these series were replaced by a new publication series "U.S. Geological Survey Water-Data Reports." This series combines under one cover streamflow data, water-quality data for surface and ground water, and ground-water level data for each state. For Pennsylvania the title is "Water Resources Data for Pennsylvania--Water Year (date), and is published in three volumes for each water year. Volume 1.--Delaware River Basin, Volume 2.--Susquehanna and Potomac River Basins, and Volume 3.--Ohio River and St. Lawrence River Basins. A limited supply of current volumes are available from the District office. Additional volumes may be purchased from:

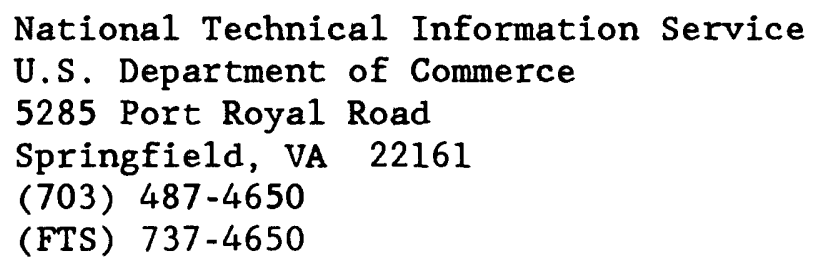

Methods for estimating the magnitude and frequency of floods for selected streams are given in the Water-Supply Paper series "Magnitude and Frequency of Floods in the United States," which is composed of reports released in parts by drainage basins; data for Pennsylvania are in Parts 1, 3, and 4. The U.S. Geological Survey also outlines flood-prone areas on topographic maps as part of a nationwide Federal program for managing flood losses. In Pennsylvania, 757 of these maps have been completed. 
P 271. The natural channel of Brandywine Creek, Pa., by M. G. Wolman. 1955.

P 282-F. Drainage basins, channels, and flow characteristics of selected streams in central Pennsylvania, by L. M. Brush, Jr., 1961.

$P$ 381. Water resources of the Delaware River basin, by G. G. Parker, A. G. Hely, W. B. Keighton, F. H. Olmsted, and others. 1964 (1965).

P 417-A. Relation between ground water and surface water in Brandywine Creek basin, Pennsylvania, by F. H. Olmsted and A. G. Hely. 1962.

P 417-B. Some relations between streamflow characteristics and the environment in the Delaware River region, by $A$. G. Hely and F. H. Olmsted. 1963.

P 473-B. Field investigation of mine waters in the Northern Anthracite field, Pennsylvania, by Ivan Barnes, W. T. Stuart, and D. W. Fisher. 1964.

P 575-C. Geological Survey Research 1967. Contains the following articles, which are not available separate1y. The construction and use of flow-volume curves, by E. G. Miller. Hydrogeologic significance of calcium-magnesium ratios in ground water from carbonate rocks in the Lancaster quadrangle, southeastern Pennsylvania, by Harold Meisler and A. E. Becher.

P 700-B. Geological Survey Research 1970. Contains the following article, which is not available separately. High-calcium limestone deposits in Lancaster County, southeastern Pennsylvania, by A. E. Becher and Harold Meisler. 
P 701-A. Hydrology of two small river basins in Pennsylvania before urbanization, by R. A. Miller, John Troxe11, and L. B. Leopold with a section on Observations of stream fauna, by Ruth Patrick and R. R. Grant, Jr. 1971 (1972).

P 750-D. Geological Survey Research 1971. Contains the following article, which is not available separately. Relationship between ground-water levels and quality in shallow observation wells in Muddy Creek basin, southeastern York County, $\mathrm{Pa}$., by D. J. Growitz and O. B. Lloyd, Jr.

P 800-C. Geological Survey Research 1972. Contains the following article, which is not available separately. An evaluation of the use of herbicides to control aquatic weeds in six Pennsylvania recreation lakes, by J. L. Barker.

P 813-I. Summary appraisals of the Nation's ground-water resources-Mid-Atlantic region, by Allen sinnott and E. M. Cushing. 1978 .

P 813-J. Summary appraisals of the Nation's ground-water resources-Great Lakes region, by W. E. Weist, Jr. 1978

P 924 .

Hurricane Agnes rainfall and floods, June-July 1972, by J. F. Bailey, J. L. Patterson, and J. L. H. Paulhus. 1975.

P 1191. Storm-induced debris avalanching and related phenomena in the Johnstown area Pennsylvania, with references to other studies in the Appalachians, by J. S. Pomeroy. 1980 (1981). 
P 1211. Johnstown-western Pennsylvania storms and floods of July 19-20, 1977, by L. R. Hoxit, R. A. Maddox, and C. F. Chappe11, National Oceanic and Atmospheric Administration, and S. A. Brua, U.S. Geological Survey. 1982.

U.S. Geological Survey Water-Supply Papers

W 106. Water resources of the Philadelphia district, by Florence Bascom. 1904.

W 108. Quality of water in the Susquehanna River drainage basin, by M. 0 . Leighton, with an introductory chapter on Physiographic features, by G. B. Hollister. 1904.

W 109. Hydrography of the Susquehanna River drainage basin, by J.C. Hoyt and R. H. Anderson. 1905.

W 161. Quality of water in the upper Ohio River basin and at Erie, Pa., by S. J. Lewis, 1906.

W 799. The floods of March 1936--Part 2, Hudson River to Susquehanna River region. 1937 (1938).

W 800. The floods of March 1936--Part 3, Potomac, James and upper Ohio River; with a section on the Weather associated with the floods of March 1936, by Stephen Lichtblau. 1937 (1938).

W 915. Major winter and nonwinter floods in selected basins in New York and Pennsylvania, by $W$. B. Langbein and others. 1947.

W 1134-B. Floods of July 18, 1942, in northcentral Pennsylvania, by $W$. S. Eisenlohr, Jr., with a section on Descriptive details of the storm and floods, by J. E. Stewart. 1952, p. 59-158. 
W 1420. Floods of August-October 1955, New England to North Carolina, by D. B. Bogart, 1960 .

W 1473. Study and interpretation of the chemical characteristics of natural water, by J. D. Hem. 1970 .

W 1526. Hydraulic and hydrologic aspects of flood-plain planning, by $S$. W. Wiitala, K. R. Jetter, and A. J. Sommerville. 1961.

W 1532-C. Effects of agricultural conservation practices on the hydrology of Corey Creek basin, Pennsylvania, 1954-60, by B. L. Jones. 1966.

W 1532-E. Hydrology and sedimentation of Corey Creek and E1k Run basins, northcentral Pennsylvania, by L. A. Reed. 1971.

W 1532-F. Appraisal of stream sedimentation in the Susquehanna River basin, by K. F. Williams and L. A. Reed. 1972 .

W 1532-H. Sediment transport by streams draining into the Delaware Estuary, by L. J. Mansue and A. B. Commings, 1974.

W 1535-P. Chemical composition of atmospheric precipitation in the Northeastern United States, by F. J. Pearson, Jr., and D. W. Fisher. 1971.

W 1539-H. Ground-water resources of Olmsted Air Force Base, Middletown, Pa., by Harold Meisler and S. M. Longwill. 1961.

W 1586-B. Salinity of the Delaware estuary, by Bernard Cohen and L. T. McCarthy, Jr. 1962 .

W 1586-G. Fresh-water discharge--salinity relations in the tidal Delaware River, by W. B. Keighton. 1966.

W 1619-W. Chemical quality of surface waters in Pennsylvania, by C. N. Durfor and P. W. Anderson. 1963. 
W 1779-B. Variations in the chemical character of the Susquehanna River at Harrisburg, Pa., by P. W. Anderson. 1963.

W 1779-C. Chemical quality of surface water in the West Branch, Susquehanna River basin, Pennsylvania, by E. F. McCarren. 1964.

W 1779-X. Quality of Delaware River water at Trenton, N. J., by L. T. McCarthy, $\mathrm{Jr}$., and W. B. Keighton. 1964.

W 1798-M. Sediment characteristics of five streams near Harrisburg, $\mathrm{Pa}$, before highway construction, by L. A. Reed. 1976.

W 1798-N. Hydrology and sedimentation of Bixler Run basin, central Pennsylvania, by L. A. Reed. 1976.

W 1800. The role of ground water in the national water situation, by C. L. McGuinness. 1963.

W 1809-0. Delaware River water quality, Bristol to Marcus Hook, Pa., August 1949 to December 1963 , by W. B. Keighton. 1965.

W 1812. Public water supp1ies of the 100 largest cities in the United States, 1962, by C. N. Durfor and Edith Becker. 1964.

W 1829. Swatara Creek basin of southeastern Pennsylvania--An evaluation of its hydrologic system, by $W$. T. Stuart, W. J. Schneider, and J. W. Crooks. 1967.

W 1835. Chemical quality of surface water in the Allegheny River basin, Pennsylvania and New York, by E. F. McCarren. 1967.

W 1871. Water data for metropolitan areas, compiled by W. J. Schneider. 1968. 
W 1879-H. Water quality and discharge of streams in the Lehigh River basin, Pennsylvania, by E. F. McCarren and W. B. Keighton. 1969.

W 1899-I. Streamflow from the United States into the Atlantic Ocean during 1931-60, by C. D. Bue. 1970.

W 1990. Annotated bibliography on artificial recharge of ground water, 1955-67, by D. C. Signor, D. J. Growitz, and William Kam. 1970.

W 1990-0. Water quality of streams in the Neshaminy Creek basin, Pennsylvania, by E. F. McCarren. 1972 .

W 2020. Subsurface waste disposal by means of wells--A selective annotated bibliography, by D. R. Rima, E. B. Chase, and B. M. Myers. 1971.

W 2035. Geohydrologic reconnaissance of the upper Potomac River basin, by F. W. Trainer and F. A. Watkins, Jr. 1975 .

W 2042. Mean annual runoff in the Upper Ohio River basin, 1941-70, and its historical variation, by $R$. M. Beall. 1978 .

W 2054. Effectiveness of sediment-control techniques used during highway construction in central Pennsylvania, by L. A. Reed. 1978 .

W 2072. Suspended-sediment discharge, in five streams near Harrisburg, Pennsylvania, before, during, and after highway construction, by L. A. Reed. 1980 .

W 2250. National water summary 1983; hydrologic events and issues. 1984. 
W 2256-A. Distribution and transport of trace substances in the Schuylkill River basin from Berne to Philadelphia, Pennsylvania, by J. K. Stamer, T. H. Yorke, and G. L. Pederson, 1985. (Supersedes Open-file report 83-265).

W 2256-B. Effects of low-level dams on the distribution of sediment, trace metals, and organic substances in the lower Schuylkill River basin, Pennsylvania, by T. H. Yorke, J. K. Stamer, and G. L. Pederson, 1985.

W 2262. Organochlorine pesticide and polychlorinated biphenyl residues at four trophic levels in the Schuylkill River, Pennsylvania: IN, Selected Papers in the Hydrologic Sciences, by J. L. Barker, 1984.

W 2275. National water summary 1984; hydrologic events, selected water-quality trends, and ground-water resources. 1985.

W 2276. Techniques for estimating streamflow characteristics in the Eastern and Interior coal provinces of the United States, by K. L. Wetzel and J. M. Bettandorff. 1986.

W 2300. National water summary 1985; hydrologic events and surface-water resources. 1986.

W 2325. National water summary 1986; hydrologic events and ground-water quality. 1988.

W 2284. Evaluation of the ground-water resources of the Lower Susquehanna River basin, Pennsylvania and Maryland, by J.M. Gerhart and G.J. Lazorchick. 1988 .

\section{Bulletins}

1245-G. Carbonate rocks of Cambrian and Ordovician age in the Lancaster quadrangle, by Harold Meisler and A. E. Becher. 1968.

1331-A. Mississippian stratigraphy of northeastern Pennsylvania, by G. R. Schiner and G. E. Kimmel. 1972 . 


\section{U.S. Geological Survey Circulars}

C-104. Water resources of southeastern Bucks County, Pa., by J. B. Graham, J.W. Mangan and W. E. White, Jr. 1951.

C-174. Water resources of the Lake Erie shore region in Pennsylvania, by J. W. Managan, D. W. Van Tuyl, and W. F. White, Jr. 1952 .

C-204. Floods in Youghiogheny and Kiskiminetas River basins, Pennsy1vania and Maryland, frequency and magnitude. 1952 .

C-257. The use of water in Pennsylvania, 1951 , by J. W. Mangan and J. B. Graham, 1953.

C-315. Water resources of the Pittsburgh area, Pennsylvania, by Max Noecker, D. W. Greenman, and N. H. Beamer. 1954.

C-377. Floods of August 1955 in the northeastern States, 1956. (See WaterSupply Paper 1420.)

C-439. Time and travel of water in the Ohio River, Pittsburgh to Cincinnati, by R. E. Steacy. 1961 .

C-526. Stream quality in Appalachia as related to coal-mine drainage, 1965, by J. E. Biesecker and J. R. George. 1966.

C-554. Hydrology for urban land planning-A guidebook on the hydrologic effects of urban land use, by L. B. Leopold. 1968.

C-601-A. Water for the cities--The outlook, by W. J. Schneider and A. M. Spieker. 1969 (1970).

C-601-D. Water as an urban resource and nuisance, by $\mathrm{H}$. E. Thomas and W. J. Schneider. 1970.

C-601-E. Sediment problems in urban areas, by H. P. Guy, 1970. 
C-601-F. Hydrologic implications of solidwaste disposal, by $W$. J. Schneider. 1970 .

C-601-G. Real-estate lakes, by D. A. Rickert and A. M. Spieker. 1971 (1972).

C-601-H. Role of water in urban planning and management, by $W$. J. Schneider, D. A. Rickert, and A. M. Spieker. 1973.

C-601-I. Water facts and figures for planners and managers, by J. H. Feth. 1973.

C-601-J. Extent and development of urban flood plains, by W. J. Schneider and J. E. Goddard. 1974.

C-601-K. An introduction to the processes, problems, and management of urban lakes, by L. J. Britton, R. C. Averett, and R. F. Ferreira. 1975. (Circular 601 issued only as separate chapters under the general title "Water in the urban environment.")

C-645. A procedure for evaluating environmental impact, by L. B. Leopold, F. E. Clark, B. B. Hanshaw, and J. R. Balsley. 1971.

C-670. Fluvial-sediment discharge to the ocean from the conterminous United States, by W. F. Curtis, J. K. Culbertson, and E. B. Chase. 1973.

C-685. Dissolved-solids discharge to the oceans from the conterminous United States, by D. K. Leifeste. 1974.

C-686. Large rivers of the United States, by $K$. T. Iseri and $W$. B. Langbein, 1974.

C-703. Water demands for expanding energy development, by G. H. Davis and L. A. Wood. 1974. 
C-719. The National Stream Quality Accounting Network (NASQAN)--Some questions and answers, by J. F. Ficke and R. O. Hawkinson. 1975.

C-728. Landsliding in Allegheny County, Pa., by R. P. Briggs, J. S. Pomeroy, and W. E. Davies. 1975.

C-745. Water consumption by nuclear powerplants and some hydrological implications, by E. V. Giusti and E. I. Meyer. 1977 (1978).

C-747. Environmental geology, Allegheny County and vicinity, Pennsylvania-Description of a program and its results, by R. P. Briggs. 1977.

C-779. Geologic disposal of high-level radioactive wastes--Earth-science perspectives, by J. D. Bredehoeft, A. W. England, D. B. Stewart, N. J. Trask, and I. J. Winograd, 1978.

C-832. Estimating the costs of landslide damage in the United States, by R. W. Fleming and F. A. Taylor. 1980 .

C-900. Guide to obtaining USGS information, by K. Dodd, H. K. Fuller, and P. F. Clarke, 1985. (This circular supersedes $(-777)$.

Journal of Research of the U.S. Geological Survey

Armbruster, J. T., 1976, An infiltration index useful in estimating low flows of drainage basins: v. 4, p. 533-538.

Barker, J. L., 1976, Effects of air injection at Prompton Lake, Wayne County, Pennsy1vania: v. 4 , no. 1, p. 19-25.

Ritter, J. R., 1974, The effects of the Hurricane Agnes Flood on channel geometry and sediment discharge of selected streams in the Susquehanna River basin, Pennsylvania: v. 2 , no. 6, p. 753-761. 


\section{Water-Resources Investigations Reports}

WRI

$50-74$.

WRI

$6-75$.

WRI

$76-51$.

WRI

76-57.

WRI

$76-66$.

WRI

$76-84$.

WRI

$76-111$.

WRI

77-12.
Stream reconnaissance for nutrients and other water-quality parameters, Greater Pittsburgh region, Pennsylvania, by R. M. Beall. 1975. (PB-241 493/AS)

Occurrence of pesticide residues in four streams draining different land-use areas in Pennsylvania, by J. F. Truhlar and L. A. Reed. 1975. (PB-242 770/AS)

Technical manual for estimating lowflow frequency characteristics of streams in the Susquehanna River basin, by J. T. Armbruster. 1976. (PB-255 455/AS)

Preimpoundment water quality of Raystown Branch Juniata River and six tributary streams, southcentral Pennsylvania, by D. R. Williams. 1976. (ADA-027 387)

Preliminary results of preimpoundment water-quality studies in the Tioga River basin, Pennsylvania and New York, by J. R. Ward. 1976. (ADA-029 315)

Limnological survey of Sacony Creek basin, Berks County, Pennsylvania by J. L. Barker and K. P. Kulp. 1976. (PB-257 270/AS)

Sediment discharge from an area of highway construction, Applemans Run basin, Columbia County, Pennsylvania, by D. A. V. Eckhardt. 1976 (1977). (PB-263 616/AS)

Flow routing in the Susquehanna River basin: Part I, effects of Raystown Lake on the low-flow frequency characteristics of the Juniata and lower Susquehanna Rivers, Pennsylvania, by J. T. Armbruster. 1977. (PB 268 981/AS) 
WRI

77-55.

WRI/OF

77-67.

WRI

78-12.

WRI

$78-35$.

WRI

$78-42$.

WRI

$78-53$.

WRI

$79-3$.

WRI

79-19.
Water-quality study of Tulpehocken

Creek, Berks County, Pennsylvania, prior to impoundment of Blue Marsh Lake, by J. L. Barker, 1977.

(AD A045 865)

Ground-water resources of Chester County, Pennsylvania, by L. J . McGreevy and R. A. Sloto.

Regional analysis of the effects of land use on stream-water quality, methodology and application in the Susquehanna River basin, Pennsylvania and New York, by D. J. Lystrom, F. A. Rinella, D. A. Rickert, and Lisa Zimmermann. 1978. (PB-284 185)

Sediment discharge from highway construction near Port Carbon, Pennsylvania, by R. E. Helm. 1978. (PB-280 793)

Postimpoundment survey of waterquality characteristics of Raystown Lake, Huntingdon and Bedford Counties, Pennsylvania, by D. R. Williams. 1978 (1979). (AOA-061 737)

Bacteriological water quality of Tulpehocken Creek basin, Berks and Lebanon Counties, Pennsylvania, by J. L. Barker. 1978 (1979). (ADA-057 485)

Regional stochastic generation of streamflows using an arima $(1,0,1)$ process and disaggregation, by J. T. Armbruster, 1979. (PB 300 945/AS)

Selected water resources data, Clarion River and Redbank Creek basins, northwestern Pennsylvania --Part 2, by T. F. Buckwalter, C. H. Dodge, and G. R. Schiner. 1979. (PB-80 107 915) 
WRI

79-52.

WRI

79-85.

WRI

79-88.

WRI

80-02.

WRI

80-53.

WRI

80-68.

WRI

81 - 1 .

WRI

81-69.
Flow routing in the Susquehanna River basin: Part II--Low-flow characteristics of the Susquehanna River between Waverly, New York and Sunbury, Pennsylvania, by D. L. Bingham. 1979.

(PB-301 392)

Flow routing in the Susquehanna River basin: Part III--Routing reservoir releases in the Tioga and Chemung Rivers system, Pennsylvania, and New York, 1977, by J. T. Armbruster. 1979. (PB-301 393)

Nonpoint-source discharges in Pequea Creek basin, Pennsylvania, 1977, by J. R. Ward and D. A. Eckhardt. 1979. (PB-175 656)

Development of a digital model of ground-water flow in deeply weathered crystalline rock, Chester County, Pennsylvania, by L. J. McGreevy and R. A. Sloto. 1980 (1981). (PB-81 132 896)

Effects of strip mining the abandoned deep Anna $S$ mine on the hydrology of Babb Creek, Tioga County, Pennsylvania, by L. A. Reed, 1980. (PB 81121 337)

The effects of highway construction on sediment discharge into Blockhouse Creek and Steam Valley Run, Pennsylvania, by R. A. Hainly, 1981. (PB-81 202 202)

Preimpoundment water quality in the Tioga River basin, Pennsylvania, and New York, by J. R. Ward. 1981. (ADA-101 909)

Sedimentation in the East Branch Mahoning Creek, Clearfield and Jefferson Counties, Pennsylvania, June 1979 to June 1980, by K. L. Wetzel. 
WRI/OF

$81-70$.

WRI

$81-73$.

WRI/OF

$81-537$.

WRI/OF

$81-538$.

WRI

$82-21$.

WRI/OF

83-223.

WRI/OF

$82-647$.

WRI

$82-4020$.

WRI

$82-4049$.

WRI

$83-4032$.
Water resources of the Clarion River and Redbank Creek basins, northwestern Pennsylvania, by $T$. F. Buckwalter, C. H. Dodge, G. R. Schiner, and H. E. Koester.

A stormwater management model for the West Branch Brandywine Creek, Chester County, Pennsylvania, by R. A. Sloto.

Hydrology of Area 3, Eastern Coal

Province, Pennsylvania, by W. J . Herb, L. C. Shaw, and D. E.

Brown.

Hydrology of Area 5, Eastern Coal

Province, Pennsylvania, Maryland, and West Virginia, by W. J. Herb, L. C. Shaw, and D. E. Brown.

Evaluation of the streamflow data program in Pennsylvania, by

H. N. Flippo, Jr.

Hydrology of Area 1, Eastern Coal

Province, Pennsylvania, by $W$. J .

Herb, D. E. Brown, L. C. Shaw, and A. E. Becher.

Hydrology of Area 2, Eastern Coa1 Province, Pennsylvania and New York, by W. J. Herb, D. E. Brown, L. C. Shaw, J. D. Stoner, and J. K. Felbinger.

Effect of urbanization on the water resources of Warminster Township, Bucks County, Pennsylvania, by R. A. Sloto and D. K. Davis.

Flow-routing in the Susquehanna River

Basin: Part V-Flow routing models for the West Branch Susquehanna River Basin, Pennsylvania, by S. A. Brua.

Water-quality assessment of Francis E. Walter Reservoir, Luzerne and Carbon Counties, Pennsylvania, by J. L. Barker. 
WRI

83-4113.

WRI

83-4164.

WRI

$83-4216$.

WRI

$83-4274$.

WRI

84-4189.

WRI

84-4223.

WRI

84-4327.

WRI

84-4335.

WRI

84-4362.
Effects of specific land uses on nonpoint sources of suspended sediment, nutrients, and herbicides - Pequea Creek basin, Pennsylvania 1979-80, by P. L. Lietman, J. R. Ward, and

T. E. Behrendt.

Water-quality and chemical loads of the Susquehanna River at

Harrisburg, Pennsylvania, April 1980 to March 1981, by D. K.

Fishe1.

Calculating sediment discharge from a highway construction site in Central Pennsylvania, by L. A. Reed, J. R. Ward, and K. L. Wetzel.

Reconnaissance of mine drainage in the coal fields of Eastern Pennsylvania, by D. J. Growitz, L. A. Reed, and M. M. Beard.

Temperature of ground water at Philadelphia, Pennsylvania, 19791981, by G. N. Paulachok.

Trap efficiency of a sediment-control pond below a block-cut coal mine in Fayette County, Pennsylvania, by

L. A. Reed, L. Dilissio, and

D. E. Stump, Jr.

Evaluation of the ground-water resources of parts of Lancaster and Berks Counties, Pennsylvania, by J. M. Gerhart and G. J. Lazorchick.

Estimating iron and aluminum content of acid mine discharge from a North-Central Pennsylvania coal field by use of acidity titration curves, by $A$. N. Ott.

Effects of surface mining on streamflow, suspended sediment, and water quality in the stony Fork drainage basin, Fayette County, Pennsylvania, by D. E. Stump, Jr. and T. M. Mastrilli. 
WRI

85-4008.

WRI

85-4023.

WRI

85-4025.

WRI

85-4038.

WRI

85-4074.

WRI

85-4077.

WRI

85-4093.

WRI

85-4177.

WRI

85-4185.
Statistical analyses of flood frequency, low-flow frequency, and flow duration of streams in the Philadelphia area, Pennsylvania, by A. Voytik.

Results of a preimpoundment waterquality study of Swatara Creek, Pennsylvania, by D. K. Fishel and J. E. Richardson.

Areal and temporal variablity of selected water quality characteristics in two hydrologic-benchmark basins in the Northeastern United States, by R. A. Hainly and J. R. Ritter.

Quality of water in mines in the western middle coal field, anthracite region, East-Central Pennsylvania, by L. A. Reed, M. M. Beard, and D. J. Growitz.

Temporal changes in sulfate, chloride, and sodium concentrations in four Eastern Pennsylvania streams, by J. L. Barker.

Cost effectiveness of the streamgaging program in Pennsylvania, by H. N. Flippo, Jr. and T. E. Behrendt.

Effects of surface coal mining on suspended-sediment discharge in a small mountain watershed, Fayette County, Pennsylvania, by T. M. Mastrilli and D. E. Stump, Jr.

Determination of benthic-invertebrate indices and water-quality trends of selected streams in Chester County, Pennsylvania, 1969-80, by C. R. Moore

Simulation of ground-water flow in aquifers along the Susquehanna River in Columbia County, Pennsylvania, by J. H. Williams and G. E. Senko 
WRI

85-4202.

WRI

85-4213.

WRI

85-4224.

WRI

85-4250.

WRI

85-4331.

WRI

85-4341.

WRI

86-4054.

WRI

$86-4055$.

WRI

$86-4164$.

WRI

$86-4352$.
Occurrence of nitrate and herbicides in ground water in the upper Conestoga River basin, Pennsylvania, by D. K. Fishel and P. L. Lietman.

Sediment loads, discharges, and yields in the East Branch Mahoning Creek basin, Clearfield and Jefferson Counties, Pennsylvania, by C. A. Loper and K. L. Wetzel

Ground-water levels in the lower Paleozoic carbonate rocks of Western Chester Valley, Chester County, Pennsylvania, November 1984 , by C. R. Wood

Surface-water quality in Pequea Creek basin, Pennsylvania, by J. R. Ward

Low-flow routing in the Lehigh and Delaware Rivers, Pennsylvania, by H. N. Flippo, Jr.

Ground-water levels in the Cockeysville marble of Southern Chester County, Pennsylvania, 1983-84, by D. W. Speight

Effects of flood controls proposed for West Branch Brandywine Creek, Chester County, Pennsylvania, by R. A. Sloto

Simulation of ground-water flow in the lower sand unit of the PotomacRaritan-Magothy aquifer system, Philadelphia, Pennsylvania, by R. A. Sloto

Hydrogeology and ground-water quality at a land reclamation site, Neshaminy State Park, Pennsylvania, by R. S. Blickwedel

Ground-water levels in the lower Paleozoic and Precambrian crystalline rocks, Southeastern Chester County, Pennsylvania, July and August 1986, by J. A. Garges 
WRI

87-4065.

WRI

$87-4098$.

WRI

87-4194.

WRI

$87-4196$.

WRI

$87-4218$.

WRI

$88-4052$.

WRI

$88-4087$.

WRI

$88-4095$.

WRI

$89-4043$.
Water resources of 0ley Township, Berks County, Pennsylvania, by G. N. Paulachok and C. R. Wood

Effect of urbanization on the water resources of Eastern Chester County, Pennsylvania, by R. A. Sloto

Estimation of flood-frequency characteristics and the effects of urbanization for streams in the Philadelphia, Pennsylvania area, by J. R. Bailey, W. O. Thomas, K. L. Wetzel, and T. J. Ross

Effects of urbanization on storm runoff volume and peak discharge of Valley Creek, Eastern Chester County, Pennsylvania, by R. A. S1oto

Geohydrology of the Furnace Creek basin and vicinity, Berks, Lancaster, and Lebanon Counties, Pennsylvania, by L. D. Cecil

Ground-water levels in the lower Paleozoic and Precambrian crystalline rocks of East Bradford and West Bradford Townships, Chester County, Pennsylvania, July and August 1987, by J. A. Garges

Preimpoundment hydrologic conditions in the Swatara Creek (1981-84) and estimated postimpoundment water quality in and downstream from the planned Swatara State Park Reservoir, Lebanon and Schuylkill Counties, Pennsylvania, by D. K. Fishel

Withdrawals and consumptive use of water in Pennsylvania, 1984, by C. A. Loper, S. D. Lent, and K. L. Wetzel

Altitude and configuration of the potentiometric surface in the Triassic sandstones and shales, Northeastern Chester County, Pennsylvania, September 1987 through January 1988, by L. A. Senior and J. A. Garges 
Hydrologic Investigations Atlases are sold by Map Distribution Section, U.S. Geological Survey, Federal Center, Box 25286, Denver, CO 80225.

HA-57. Floods at Harrisburg, Pennsylvania, by R. E. Steacy and I. A. Heckmiller. 1962 .

HA-61. Stream composition of the conterminous United States, by F. H. Rainwater. 1962 .

HA-194. Generalized maps showing annual runoff and productive aquifers in the conterminous United States, compiled by C. L. McGuinnes. 1964.

HA-198. Water resources of the Appalachian region, Pennsylvania to Alabama, by W. J. Schneider and others. 1965.

HA-199. Preliminary map of the conterminous United States showing depth to and quality of shallowest ground water containing more than 1,000 parts per million dissolved solids, by J. H. Feth and others. 1965.

HA-200. Chemical quality of public water supplies of the United States and Puerto Rico, 1962, by C. N. Durfor and Edith Becker. 1964.

HA-212. Annual runoff in the conterminous United States, by J. F. Blakey. 1966.

HA-246. Floods at Easton, Pennsylvania-Phillipsburg, New Jersey, by G. M. Farlekas, 1967.

HA-248. Floods on the Schuylkill River from Conshohocken to Philadelphia, Pennsylvania, by A. T. Alter. 1967.

HA-295. Ground-water resources of the Appalachian Region, by G. G. Wyrick, 1968 .

HA-335. Water quality in the Delaware estuary for the two years of drought, 1965-1966, from Trenton, New Jersey, to Reedy Island, Delaware, by W. B. Keighton. 1969. 
HA-483. Extent and frequency of floods on the Schuylkill River near Norristown, Pennsylvania, by W. F. Busch and L. C. Shaw. 1973.

HA-523. Flood of June 1972 in the Wilkes-Barre area, Pennsylvania, by H. N. Flippo and L. W. Lenfest, Jr. 1973.

HA-530. Flood of June 1972 in the Harrisburg area, Pennsylvania, by L. V. Page and L. C. Shaw. 1974.

HA-541. Flood of June 22-23, 1972, at Lock Haven, Pennsylvania, by $H . N$. Flippo, Jr. 1975.

HA-676. Water-table map of Philadelphia, Pennsylvania, 1976-1980, by G. N. Paulachok and C. R. Wood, 1984. 


\section{U.S. Geological Survey Open-File Reports and Maps}

Open-file reports which may be in manuscript form, generally are not reproduced and distributed in quantity. These reports are available for inspection in the Harrisburg, Pennsylvania and the Reston, Va. offices of the U.S. Geological Survey. Most numbered open-file reports may be purchased from the Books and Open-File Reports Section (BOFRS). Information on the availability of the unnumbered reports may be obtained from the District Chief, U.S. Geological Survey-WRD, Harrisburg, Pennsylvania.

\section{Numbered Open-File Reports}

76-247. Time-of-travel studies Susquehanna River, Binghamton, New York, to Clarks Ferry, Pennsylvania, by C. D. Kauffman, Jr., J. T. Armbruster, and Andrew Voytik, 1976.

76-350. Map showing selected extremestreamflow statistics and drainage areas, Greater Pittsburgh region, Pennsylvania, by $M$. B . Coll, Jr., and R. M. Beall, 1976 .

76-352. Guide to the availability of hydrologic data, greater Pittsburgh region, Pennsylvania, by R. M. Beal1, 1976.

76-445. Selected hydrologic data, Clarion River and Redbank Creek basins, northwestern Pennsylvania--An interim report, by $\mathrm{H}$. E. Koester and Joseph Lescinsky, 1976.

76-793. Ground-water conditions in the Kingston area, Luzerne County, Pennsylvania, and their effect on basement flooding, by $D$. J. Growitz, 1976.

77-462. Limnological studies of the major streams in Chester County, Pennsylvania, by B. W. Lium, 1977.

77-479. Water loss from Jordan Creek near Allentown, Pennsylvania--1973 to 1976 , by R. E. Steacy, 1977. 
78-819. Water-quality investigation of Francis Slocum Lake, Luzerne County, Pennsylvania, by

J. L. Barker, 1978.

78-963. Floods of July 19-20, 1977, in the Johnstown area, western Pennsylvania, by S. A. Brua, 1978 .

80-566. Work plan for the Schuylkill River basin, Pennsylvania: Assessment of river quality as related to the distribution and transport of trace metals and organic substances, by G. L. Pederson, T. H. Yorke, and J. K. Stamer, 1980 .

80-1119. Ground-water quality and data on wells and springs in Pennsy1vania, Volume I--Ohio and St. Lawrence River basins, by H. E. Koester and D. R. Miller, 1980 .

81-60. Sample mine-site permit application (hydrologic assessment), by W. J. Herb, D. M. Brown, L. D. Carswel1, and P. L. Lietman, 1981.

81-329. Ground-water quality and data on wells and springs in Pennsylvania, Volume II, Susquehanna and Potomac River basins, by H. E. Koester and D. R. Miller, 1981.

81-330. Ground-water quality and data on wells and springs in Pennsylvania, Volume III, Delaware River basin, by H. E. Koester and D. R. Miller, 1981.

81-1025. An evaluation of the effects of acid rain on low conductivity headwater streams in Pennsylvania, by J. R. Ritter and A. E. Brown, 1981. 
81-1115. An evaluation of water-quality monitoring in the Brandywine Creek basin, Pennsylvania, 1973-78, by J. J. Murphy, J. R. Ritter, A. E. Brown, and J. P. Chiarella, 1981.

82-861. Time-of-travel and dispersion studies, Lehigh River, Francis E. Walter Lake to Easton, Pennsylvania, by C. D. Kauffman, Jr, 1982 .

83-149. Hydrologic data for aquifers in Philadephia, Pennsylvania, by G. N. Paulachok, C. R. Wood, and L. J. Norton, 1984.

84-235. Water-table contour map of the carbonate rocks of eastern Chester County, Pennsylvania, October 1983, by R. A. Sloto. 1984 .

84-706. Compilation of ground-water-quality data in Pennsylvania, by $\mathrm{J}$. L. Barker, 1984.

84-715. Ground-water levels in the carbonate rocks of Central Chester County, Pennsylvania, May 18 to June 15, 1984, by C. R. Wood. 1984

86-486. Flood of November 1985 in West Virginia, Pennsylvania, Maryland, and Virginia by J. B. Lescinsky.

87-232. Map showing radium concentrations in ground water of the Chickies Formation, Southeastern Pennsylvania, 1986-87, by L. D. Cecil.

87-475. Water resources activities of the U.S. Geological Survey in Pennsylvania, $1986-87$, by R. E. Helm

88-96. Evaluation of agricultural best-management practices in the Conestoga River headwaters, Pennsylvania, by D. C. Chichester

88-149. Water Fact Sheet, U.S. Geological Survey, Department of the Interior. U.S. Geological Survey Ground-Water Studies in Pennsylvania, by C. R. Wood 
A1ter, A. T., 1966, Extent and frequency of inundation of the Schuylkill River flood plain from Conshohocken to Philadelphia, Pennsylvania.

Barker, J. L., 1972, Effects of acid mine drainage on fish and macroinvertebrates of Babb Creek, Tioga County, Pennsylvania.

1972, Effects of acid mine drainage on fish and macroinvertebrates of Loyalsock Creek near Lopez, Sullivan County, Pennsylvania.

1972, Effects of acid mine drainage on fish and macroinvertebrates of the Tioga River, Pennsylvania and New York.

Busch, W. F., 1969, Extent and frequency of inundation on the Perkiomen Creek flood plain from Green Lane Reservoir to the Schuylkil1 River (near Oaks, Pennsylvania).

Busch, W. F., and Shaw, L. C., 1960, Floods in Pennsylvania--Frequency and magnitude.

1971, Extent and frequency of floods on Schuylkill River (near Norristown, Pennsylvania).

1973, Extent and frequency of floods on the Schuylkill River near Phoenixville and Pottstown, Pennsylvania.

Farlekas, G. M., 1965, Extent and frequency of floods in vicinity of Easton, Pennsylvania to Phillipsburg, New Jersey.

Flippo, H. N., Jr., 1971, Acidity control in Bald Eagle Creek and West Branch of the Susquehanna River, Clinton County, Pennsylvania.

1971, Chemical and biological conditions in Bald Eagle Creek and prognosis of trophic characteristics of Foster Joseph Sayers Reservoir, Centre County, Pennsy1vania.

Lium, B. W., 1976, Limnological data for the major streams in Chester County, Pennsylvania. 
McCarren, E. F., Wark, J. W., and George, J. R., 1964, Water quality of the Swatara Creek

basin, Pennsylvania.

McGreevy, L. J., 1974, Seepage study of streams crossing Chester Valley, Chester County, Pennsylvania.

McGreevy, L. J., and Sloto, R. A., 1976, Selected hydrologic data, Chester County, Pennsylvania.

Ott, A. N., and Commings, A. B., 1972, An inventory of suspended sediment stations and type of data analysis.

Page, L. V., and Shaw, L. C., 1973, Flood of September 1971 in southeastern Pennsylvania.

Reed, L. A., 1971, Effects of roadway and pond construction on sediment yield near Harrisburg, Pennsylvania.

Seaber, P. R., 1968, An appraisal of the ground-water resources of the upper Susquehanna River basin.

Seaber, P. R., and Hollyday, E. F., 1965, An appraisal of the ground-water resources of the lower Susquehanna River basin.

1966, An appraisal of the Juniata River basin, Susquehanna River basin.

Wood, C. R., 1974, Evaluation of arsenic concentrations in the Tulpehocken Creek basin, Pennsylvania. 
II. Publications of Pennsylvania State Agencies Prepared in Cooperation with the U.S. Geological Survey

These reports can be obtained from the Director and State Geologist, Bureau of Topographic and Geologic Survey, Pennsylvania Department of Environmental Resources; Deputy Secretary, Office of Resources Management, Pennsylvania Department of Environmental Resources; State Book Store, P.0. Box 1365, Harrisburg, PA; or the District Chief, Water Resources Division, U.S. Geological Survey. A more complete list of State agency publications also can be obtained from any of these offices.

Adamson, J. H., Jr., Graham, J. B., and Klein, N. H., 1949, Ground-water resources of the valley-fill deposits of Allegheny County, Pennsylvania: Pennsylvania Geological Survey, 4th Ser., Water Resource Rept. W-8.

Barker, J. L., 1978, Characteristics of Pennsylvania recreational lakes: Pennsylvania Department of Environmental Resources, Water Resources Bull. No. 14.

Beamer, N. H., 1953, Chemical character of surface water in Pennsylvania, 1949-51: Pennsylvania Dept. Commerce State Planning Board Pub. 26.

Becher, A. E., 1970, Ground water in Pennsylvania: Pennsylvania Geological Survey, 4th ser., ES-3.

Becher, A. E., and Root, S. I., 1981, Ground water and geology of the Cumberland Valley, Cumberland County, Pennsylvania: Pennsylvania Geological Survey, 4th ser., Water Resource Rept. W-50.

Becher, A. E., and Taylor, L. E., 1982, Groundwater resources in the Cumberland and contiguous valleys of Franklin County, Pennsylvania: Pennsylvania Geological Survey, 4th ser., Water Resource Rept. W-53.

Bennett, G. D., and Patten, E. P., Jr., 1960, Borehole geophysical methods for analyzing the specific capacity of aquifers in a multiaquifer well: Pennsylvania Geological Survey, 4th ser., Water Resource Rept. W-12.

Biesecker, J. E., Lescinsky, J. B., and Wood, C. R., 1968, Water resources of the Schuylkill River basin: Pennsylvania Dept. of Forests and Waters, Water Resources Bull. No. 3 . 
Bourquard, E. H., and others, 1966, Report on water-resources study of Neshaminy Creek basin and vicinity--Bucks and Montgomery Counties, Pennsylvania: Pennsylvania Dept. of Forests and Waters, Water Resources Bull. No. 2 .

Busch, W. F., and Shaw, L. C., 1966, Pennsylvania streamflow characteristics--low-flow frequency and flow duration: Pennsylvania Dept. of Forests and Waters, Water Resources Bul1. No. 1 .

Carswe11, L. D., and Bennett, G. D., 1963, Geology and hydrology of the Neshannock quadrangle, Mercer and Lawrence Counties, Pennsylvania: Pennsylvania Geol. Survey, 4th ser., Water Resource Rept. W-15.

Carswe1l, L. D., Hollowel1, J. R., and Platt, L. B., 1968, Geology and hydrology of the Martinsburg Formation in Dauphin County, Pennsylvania: Pennsylvania Geol. Survey, 4th ser., Water Resource Rept. W-24.

Carswe11, L. D., and Lloyd, O. B., Jr. 1979, Geology and ground-water resources of Monroe County, Pennsylvania: Pennsylvania Geol. Survey, 4th ser., Water Resource Rept. W-47.

Chester County Water Resources Authority, 1972, Ten Year report--1972: Chester County Water Resources Authority, Misc. State Agency Rept.

Flippo, H. N., Jr., 1974, Springs of Pennsylvania: Pennsylvania Dept. of Environmental Resources, Water Resources Bull. No. 10.

1975, Temperatures of streams and selected reservoirs in Pennsylvania: Pennsylvania Dept. of Environmental Resources, Water Resources Bull. No. 11 .

1977, Floods in Pennsylvania: Pennsy1vania Dept. of Environmental Resources, Water Resources Bul1. No. 13.

1982, Technical manual for estimating low-flow characteristics of Pennsylvania streams: Pennsylvania Dept. of Environmental Resources, Water Resources Bull. No. 15. 
Gallaher, J. T., 1973, Summary of ground-water resources of Allegheny County, Pennsylvania: Pennsylvania Geol. Survey, 4th ser., Water Resource Rept. W-35.

Greenman, D. W., 1955, Ground-water resources of Bucks County, Pennsylvania: Pennsylvania Geol. Survey, 4th ser., Water Resource Rept. W-11.

Greenman, D. W., and others, 1961. Ground-water resources of the Coastal Plain area of southeastern Pennsylvania, with special reference to effects of human activities on the quality of water in the Coastal Plain sediments: Pennsylvania Geol. Survey, 4th ser., Water Resource Rept. W-13.

Hall, G. M., 1934, Ground water in southeastern Pennsylvania: Pennsylvania Geol. Survey, 4 th ser., Water Resource Rept. W-2.

Hollowel1, J. R., 1971, Hydrology of the Pleistocene sediments in the Wyoming Valley, Luzerne County, Pennsylvania: Pennsylvania Geol. Survey, 4th ser., Water Resource Rept. W-28.

Hollowell, J. R., and Koester, H. E., 1975, Ground-water resources of Lackawanna County, Pennsylvania: Pennsylvania Geol. Survey, 4th ser., Water Resource Rept. W-41.

Johnston, H. E., 1966, Hydrology of the New Oxford Formation in Lancaster County, Pennsylvania: Pennsylvania Geol. Survey, 4th ser., Water Resource Rept. W-23.

1970, Ground-water resources of the Loysville and Mifflintown quadrangles in south-central Pennsylvania: Pennsylvania Geol. Survey, 4th ser., Water Resource Rept. W- 27 .

Leggette, R. M., 1936, Ground water in northwestern Pennsylvania: Pennsylvania Geol. Survey, 4th ser., Water Resource Rept. W-3.

Lloyd, O. B., and Carswe11, L. D., 1981, Groundwater resources of the Williamsport Region, Lycoming County, Pennsylvania: Pennsylvania Geol. Survey, 4th ser., Water Resource Rept. W- 51 . 
Lloyd, O. B., Jr., and Growitz, D. J., 1976, Ground-water resources of central and southern York County, Pennsylvania: Pennsylvania Geol. Survey, 4th ser., Water Resource Rept. W-42.

Lohman, S. W., 1937, Ground water in northeastern Pennsylvania: Pennsylvania Geol. Survey, 4th ser., Water Resource Rept. W-4.

1938, Ground water in south-central Pennsylvania: Pennsylvania Geol. Survey, 4th ser., Water Resource Rept. W-5.

1939, Ground water in north-central Pennsylvania: Pennsylvania Geol. Survey, 4th ser., Water Resource Rept. W-6.

1941, Ground-water resources of Pennsylvania: Pennsylvania Geol. Survey, 4th ser., Water Resource Rept. W-7.

Longwi11, S. W., and Wood, C. R., 1965, Ground-water resources of the Brunswick Formation in Montgomery and Bucks Counties, Pennsylvania: Pennsylvania Geo1. Survey, 4th ser., Water Resource Rept. W-22.

Meisler, Harold, 1963, Hydrogeology of the carbonate rocks of the Lebanon Valley, Pennsylvania: Pennsylvania Geol. Survey, 4th ser., Water Resource Rept. W-18.

Meisler, Harold, and Becher, A. E., 1966, Hydrology of the carbonate rocks of the Lancaster 15-minute quadrangle, southeastern Pennsylvania: Pennsylvania Geo1. Survey, 4th ser., Progress Rept. PR-171.

Miller, R. Adam, 1974, Hydrologic Data of June 1972 flood in Pennsylvania: Pennsylvania Dept. of Environmental Resources, Water Resources Bull. No. 9.

Molloy, J. J., 1960, Flood discharge records relating to Pennsylvania streams: Pennsylvania Dept. of Forests and Waters. 
Newport, T. G., 1971, Ground-water resources

of Montgomery County, Pennsylvania:

Pennsylvania Geol. Survey, 4th ser.,

Water Resource Rept. W-29.

1973, Summary of ground-water resources of Clarion County, Pennsylvania: Pennsylvania Geol. Survey, 4th ser., Water Resource Rept. W-32.

1973, Summary of ground-water resources of Westmoreland County, Pennsylvania: Pennsylvania Geol. Survey, 4th ser., Water Resource Rept. W-37.

1973, Summary of ground-water resources of Washington County, Pennsylvania: Pennsylvania Geol. Survey, 4th ser., Water Resource Rept. W-38.

1976, Summary of ground-water resources of Luzerne County, Pennsylvania: Pennsylvania Geol. Survey, 4th ser., Water Resource Rept. W-40.

O'Neil1, B. J., Jr., 1974, Greater Pittsburgh region--Construction aggregates: Pennsylvania Geol. Survey, 4 th ser., Mineral Resource Rept. M-67.

Ott, A. N., Barker, J. L., and Growitz, D. J., 1973, Physical, chemical, and biological characteristics of Conewago Lake drainage basin, York County, Pennsylvania: Pennsylvania Dept. of Environmental Resources, Water Resources Bull. No. 8.

Page, L. V., 1970, A proposed streamflow data program for Pennsylvania: Pennsylvania Dept. of Forests and Waters Tech. Bull. No. 3.

Page, L. V., and Seaber, P. R., 1970, Water resources investigations in the Susquehanna River basin: Pennsylvania Dept. of Forests and Waters Tech. Bull. No. 2.

Page, L. V., and Shaw, L. C., 1977, Low-flow characteristics of Pennsylvania streams: Pennsylvania Dept. of Environmental Resources, Water Resources Bull. No. 12. 
Patten, E. P., Jr., and Bennett, G. D., 1963, Methods of flow measurement in well bores: Pennsylvania Geol. Survey, 4th ser., Water Resource Rept. W-17.

1963, Application of electrical and radioactive well logging to ground-water hydrology: Pennsylvania Geol. Survey, 4th ser., Water Resource Rept. W-19.

Pennsylvania Department of Commerce State Planning Board, 1945, Temperatures and chemical content during low flow, JulyOctober 1944: Pennsylvania Dept.

Commerce State Planning Board Pub. 14.

1958, Industrial water supplies in Pennsylvania: Pennsylvania Dept.

Commerce State Planning Board Plant Location Factors Rept. 3.

Pennsylvania Department of Forests and Waters, 1936, The Floods of March 1936 in Pennsylvania.

1937, The drought of 1930 in Pennsylvania.

1940, Natural water losses from Pennsylvania drainage basins.

1942, Elevations of major floods along Pennsylvania rivers.

1942, The floods of May 1942 in the Delaware and Lackawanna River basins.

1943, The flood of July 1942 in the upper Allegheny River and Sinnemahoning Creek basins.

1946, Temperatures of natural waters in Pennsylvania.

1951, Forest and Water research project: Delaware-Lehigh experimental forest:

Pennsylvania Dept. of Forests and Waters Rept. 1.

1953, Forest and water research project: Delaware-Lehigh experimental forest: Pennsylvania Dept. of Forest and waters Rept. 2. 
1955, Forest and water research project:

Delware-Lehigh experimental forest: Penn-

sylvania Dept. of Forests and Waters Rept. 3.

1961, Forest and water research project:

Delaware-Lehigh experimental forest: Fenn-

sylvania Dept. of Forests and Waters Rept. 4.

Piper, A. M., 1933, Ground water in southwestern

Pennsylvania: Pennsylvania Geol. Survey,

4th ser., Water Resource Rept. W-1.

Poth, C. W., 1962, The occurrence of brine in western Pennsylvania: Pennsylvania Geol. Survey, 4th ser., Mineral Resource Rept. M-47.

1963, Geology and hydrology of the Mercer quadrangle, Mercer, Lawrence, and Butler Counties, Pennsylvania: Pennsylvania Geol. Survey, 4th ser., Water Resource Rept. W-16.

1963, The ground-water observation-well program in Pennsylvania: Pennsylvania Geol. Survey, 4th ser., Water Resource Rept. W-20.

1968, Hydrology of the metamorphic and igneous rocks of central Chester County, Pennsylvania: Pennsylvania Geol. Survey, 4th ser., Water Resource Rept. W-25.

1972, Hydrology of the Martinsburg Formation in Lehigh and Northampton Counties, Pennsylvania: Pennsylvania Geol. Survey, 4th ser., Water Resource Report. W-30.

1973, Summary of ground-water resources of Armstrong County, Pennsylvania: Pennsylvania Geol. Survey, 4th ser., Water Resource Rept. W-34.

1973, Summary of ground-water resources of Butler County, Pennsylvania: Pennsylvania Geol. Survey, 4th ser., Water Resource Rept. W-36.

1973, Summary of ground-water resources of Beaver County, Pennsylvania: Pennsylvania Geol. Survey, 4th ser., Water Resource Rept. W-39. 
1977, Summary of ground-water resources of Lancaster County, Pennsylvania: Pennsylvania Geol. Survey, 4th ser., Water Resource Rept. W-43.

Rima, D. R., Meisler, Harold, and Longwill, Stanley, 1963, Geology and hydrology of the Stockton Formation in southeastern Pennsylvania: Pennsylvania Geol. Survey, 4th ser., Water Resource Rept. W-14.

Rossow, C. J., and Col1, M. B., Jr., 1970, Water-resources investigations in the upper Ohio River basin: Pennsylvania Dept. of Forests and Waters Tech. Bull. No. 1.

Schiner, G. R., and Gallaher, J. T., 1979, Geology and ground-water resources of western Crawford County, Pennsylvania: Pennsylvania Geol. Survey, 4th ser., Water Resource Rept. W-46.

Schiner, G. R., and Kimmel, G. E., 1976, Geology and ground-water resources of northern Mercer County, Pennsylvania: Pennsylvania Geol. Survey, 4th ser., Water Resource Rept. W-33.

Shaw, L. C., and Busch, W. F., 1970, Pennsy1vania Gazetteer of streams--Part 1: Pennsylvania Dept. of Forests and Waters, Water Resources Bull. No. 6 .

Shaw, L. C., Pennsylvania Gazatteer of streams, Part II, Pennsylvania Dept. of Environmental Resources, Water Resources Bull., No. 16.

Stoner, J. D., Williams, D. R., Buckwalter, T. F., and Pattison, K. L., 1987, Water resources and the effects of coal mining, Greene County, Pennsylvania: Pennsylvania Geol. Survey, 4 th Ser., Water Resource Rept. W-63.

Ulanowski, J. T., Shertzer, R. H., Barker, J. L., and Hartman, R. T., 1981, Trophic classification and characteristics of twenty-six publically owned Pennsylvania lakes: Pennsylvania Dept. of Environmental Resources, Publication No. 61 . 
Van Tuy1, D. W., 1951, Ground water for air conditioners at Pittsburgh, Pennsylvania:

Pennsylvania Geol. Survey, 4th ser.,

Water Resource Rept. W-10.

Van Tuyl, D. W., and Klein, N. H., 1951, Groundwater resources of Beaver County, Pennsyl-

vania: Pennsylvania Geol. Survey, 4th ser., Water Resource Rept. W-9. (supplement to

Water Resource Rept. W-3).

White, W. F., Jr., and Lindholm, C. F., 1950, Water-resources investigations relating to the Schuylkill River restoration project, 1947-49: Pennsylvania Dept. of Forests and Waters.

Williams, J. H. and Eckhart, D. A., 1987, Groundwater resources of the BerwickBloomsburg-Daniels area, east-central Pennsylvania: Pennsylvania Geol. Survey, 4th ser., Water Resource Rept. W-61.

Wood, C. R., 1980 Summary ground-water resources of Centre County, Pennsylvania: Pennsylvania Geol. Survey, 4th ser., Water Resource Rept. W-48.

1980, Ground-water resources of the Gettysburg and Hammer Creek Formations Southeastern Pennsylvania: Pennsylvania Geol. Survey, 4th ser., Water Resource Rept. W-49.

Wood, C. R., Flippo, H. N., and Lescinsky, J. B., 1974, Water resources of Lehigh County, Pennsylvania: Pennsylvania Geol. Survey, 4th ser., Water Resource Rept. W-31.

Wood, C. R., and MacLachlan, D. B., 1978, Geology and ground-water resources of northern Berks County, Pennsylvania: Pennsylvania Geol. Survey, 4th ser., Water Resource Rept. W-44.

Wood, P. R., and Johnston, H. E., 1964 , Hydrology of the New Oxford Formation in Adams and York Counties, Pennsylvania: Pennsylvania Geol. Survey, 4th ser., Water Resource Rept. W-21. 


\section{Other Publications}

Address inquiries about the availability of these reports to the publishers.

Chen, C. and Armbruster, J. T., 1980, Dam-break wave model: formulation and verification: Journal of the Hydraulics Division, May, p. $747-767$.

Emrich, G. H., 1966, Ground-water geology: Pennsylvania Dept. Health Div. Sanitary Eng. Pub. No. 11.

Gerhart, J. L., 1984, An approach to regional ground-water flow modeling in secondarypermeability terrane in Pennsylvania and Maryland: Ground-Water, March-April, v. 22, no. 2, pp. 168-175.

Jones, B. L., and Unger, D. G., 1962, Measuring effects of conservation: Soil and Water Conserv. Jour., v. 17, no. 4, p. 172-174.

Lietman, P. L., Gerhart, J. M., Wetze1, K. L., 1989, Comparison of methods for sampling dissolved nitrogen in a fractured carbonaterock aquifer. Winter 1989 Ground Water Monitoring Review, p. 197-202.

Love, S. K., 1956, Quality of water in the upper Ohio River basin, -Man and the waters of the upper Ohio basin, Pymatuning Lab. Field Biology Spec. Pub. 1.

Lystrom, D. J., and Rinella, F. A., 1978, A method for estimating the regional effects of land use on river-water quality, Susquehanna River basin, Pennsylvania and New York: American Chemical Society 194, p. 732-839.

Makuch, J., and Ward, J. R., 1986, A quick look at Pennsylvania Groundwater. Pamphlet The Pennsylvania State University and the U.S. Geological Survey cooperating.

Makuch, J., and Ward, J. R., 1988, Groundwater and Agriculture in Pennsylvania. Circular 341. Published by the Pennsylvania State University. 
Paulson, R. W., 1970, Variation of the longitudinal dispersion coefficient in the Delaware River Estuary as a function of fresh water inflow: Water Resources Research, v. 6, no. 2, p. 516-526.

Richards, D. B., 1985, Ground-water information manual: Coal mine permit applications.Vol. I: Office of Surface Mining Reclamation and Enforcement. 275 p.

Richards, D. B., and others, 1987 , Ground-water information manual: Coal mine permit applications--Vol. II: Office of Surface Mining Reclamation and Enforcement. 396 p.

Romanelli, C. J., and Griffith, W. M., eds., 1974, The Wrath of Agnes--A complete pictorial and written history of the June 1972 flood in the Wyoming Valley: Wilkes-Barre, Pa., Media Affiliates, Inc., $200 \mathrm{p}$.

Sloto, R. A., 1985, Effects of Flood Controls Proposed for the Sucker Run basin, Chester County, Pennsylvania: Chester County Water Resources Authority, Water Resource Report 1.

Sopper, W. E., and Lul1, H. W., 1970, Streamflow characteristics of the northeastern United States: Pennsylvania State Univ. Co11. Agriculture Agr. Expt. Sta. Bu11. 766.

Stoner, J. D., 1983, Probable hydrologic effects of subsurface mining: Ground Water Montoring Review, Winter, v. 3, no. 1, p. 128-137.

Truhlar, J. F., 1976, Determining suspendedsediment discharge from turbidity record: Third Federal Interagency Sedimentation Conference Proceedings, Denver, Colorado, March 1976, p. 7:65-7:74.

Weber, W. G., Jr., and Reed, L. A., 1976, Sediment runoff during highway construction: Civil Engineering, March, p. 76-79. 
Listed below are reports that received Director's approval and are in final preparation for publication in 1989.

\begin{tabular}{|c|c|c|c|}
\hline $\begin{array}{l}\text { Project } \\
\text { No. }\end{array}$ & $\begin{array}{l}\text { USGS } \\
\text { Report } \\
\text { No. }\end{array}$ & Title & Author \\
\hline PA096b & $\begin{array}{l}\text { WSP } \\
2346 .\end{array}$ & $\begin{array}{l}\text { Geohydrology and ground-water resources } \\
\text { of Philadelphia, Pennsylvania }\end{array}$ & Paulachok, G. N. \\
\hline PA135 & $\begin{array}{l}\text { WRIR } \\
85-4283 .\end{array}$ & $\begin{array}{l}\text { Surface-water quality in the West Branch } \\
\text { Susquehanna River basin, Pennsylvania: } \\
\text { An appraisal of areal and temporal } \\
\text { variability from } 1962 \text { to } 1982 \text { in } \\
\text { Hydrologic Accounting Unit } 020502\end{array}$ & $\begin{array}{l}\text { Hainly, R. A. } \\
\text { Truhlar, J. F. } \\
\text { Wetzel, K. L. }\end{array}$ \\
\hline PA006 & $\begin{array}{l}\text { WRIR } \\
86-4195 .\end{array}$ & $\begin{array}{l}\text { Technique for estimating depths of } \\
100 \text {-year floods in Pennsylvania }\end{array}$ & F1ippo, H. N. \\
\hline PA138 & $\begin{array}{l}\text { WRIR } \\
87-4136 .\end{array}$ & $\begin{array}{l}\text { A feasibility study to estimate } \\
\text { minimum surface-casing depths of oil } \\
\text { and gas wells to prevent ground- } \\
\text { water contamination in four areas of } \\
\text { Western Pennsylvania }\end{array}$ & $\begin{array}{l}\text { Buckwalter, T. F } \\
\text { Squillace, P. J. }\end{array}$ \\
\hline PA108b & $\begin{array}{l}\text { WRIR } \\
88-4005 .\end{array}$ & $\begin{array}{l}\text { Suspended-sediment yields from an } \\
\text { unmined area and from mined areas } \\
\text { before and after reclamation in } \\
\text { Pennsylvania, June } 1978 \text {-September } 1983\end{array}$ & $\begin{array}{l}\text { Reed, L. A. } \\
\text { Hainley, R. A }\end{array}$ \\
\hline PA153 & $\begin{array}{l}\text { WRIR } \\
88-4211 .\end{array}$ & $\begin{array}{l}\text { Relation of ground-water quality to } \\
\text { land use in the Philadelphia, } \\
\text { Pennsylvania-Camden, New Jersey area }\end{array}$ & $\begin{array}{l}\text { Blickwedel, R. S. } \\
\text { Wood, C. R. }\end{array}$ \\
\hline PA169 & $\begin{array}{l}\text { WRIR } \\
89-4014 .\end{array}$ & $\begin{array}{l}\text { Water quality of the West Branch } \\
\text { Lackawaxen River and Iimnology of } \\
\text { Prompton Lake, Wayne County, Pennsylvania, } \\
\text { October } 1986 \text { through September } 1987\end{array}$ & Barker, J. L. \\
\hline PA137b & $\begin{array}{l}\text { WRIR } \\
89-4023 .\end{array}$ & $\begin{array}{l}\text { Distribution of water-quality } \\
\text { indicators of acid mine drainage } \\
\text { in streams of the Interior Coal } \\
\text { Province, Eastern Coal Region of } \\
\text { the United States }\end{array}$ & $\begin{array}{l}\text { Hoffman, S. A. } \\
\text { Wetzel, K. L. }\end{array}$ \\
\hline PA403 & $\begin{array}{l}\text { OFR } \\
85-686\end{array}$ & $\begin{array}{l}\text { Physical, chemical, and biological } \\
\text { data for selected streams in Chester } \\
\text { County, Pennsylvania, } 1969-80\end{array}$ & Moore, C. R. \\
\hline
\end{tabular}


PA100

$$
\text { OFR }
$$

$86-140$.

Water-quality data for precipitation

and storm runoff in Pennypack

Creek basin, Philadelphia,

Pennsylvania

PA161 OFR

$88-470$.

Hydrologic data for Indian Creek basin, Fayette and Westmoreland Counties, Pennsylvania, 1985-87

PAl37a HA 705.
Distribution of water-quality characteristics that may indicate the presence of acid mine drainage in the Eastern Coal Province of the United States
Speight, D. W.

Sams, J. I. Witt, E. C.

Wetzel, K. L. Hoffman, S. A 
Cooperative reports to be published by PaDER, Bureau of Topographic and Geologic Survey.

Project No.

PA130

PA110

PA076

PA061

PA143
Title

Ground-water resources of

Delaware County, Pennsylvania

Ground-water resources in and near the anthracite basins of Schuylkill and adjacent counties, Pennsylvania

Ground-water resources of Pike County, Pennsylvania

Hydrology and geology of

Erie County, Pennsylvania

Hydrogeology and ground-water quality of the glaciated valleys of Bradford, Tioga, and Potter Counties, Pennsylvania
Author

Balmer, W. T.

Becher, A. E.

Davis, D. K.

Gallaher, J. T.

Williams, J. H. Taylor, L. E. Low, D. J. 
Additional information on U.S. Geological Survey programs in Pennsylvania can be obtained from:

WATER

District Chief USGS - WRD

Federal Bldg., 228 Walnut St. P.0. Box 1107

Harrisburg, PA 17108

$\mathrm{Ph}: \quad$ (717) $782-3468$

\section{MAPS}

National Cartographic Information Center U.S. Geological Survey 507 National Center Room 1-C-107 12201 Sunrise Valley Drive Reston, VA 22092 $\mathrm{Ph}:$ (703) 860-6045

\section{GENERAL INFORMATION}

Public Inquiries office

Geologic Inquiries Group U.S. Geological Survey

U.S. Geological Survey 907 National Center Reston, VA 22092

Ph: (703) 648-4383
503 National Center

Room 1-C-402

12201 Sunrise Valley Drive Reston, VA 22092

$\mathrm{Ph}:$ (703) 648-6892

Several Commonwealth agencies conduct water-resources investigations and present their results in State publications. The Department of Environmental Resources, Bureau of Topographic and Geologic Survey, in addition to the cooperative studies with the U.S. Geological Survey, conducts its own water resource studies and publishes the results in their Water Resource Reports Series. A bibliography of these reports can be obtained by writing:

Pennsylvania Geological Survey Department of Environmental Resources P.0. Box 2357

Harrisburg, PA 17120 